Chapter 16

\title{
Plant Structure in the Brazilian Neotropical Savannah Species
}

\author{
Suzane Margaret Fank-de-Carvalho, \\ Nádia Sílvia Somavilla, \\ Maria Salete Marchioretto and Sônia Nair Báo \\ Additional information is available at the end of the chapter \\ http://dx.doi.org/10.5772/59066
}

\section{Introduction}

This chapter presents a review of some important literature linking plant structure with function and/or as response to the environment in Brazilian neotropical savannah species, exemplifying mostly with Amaranthaceae and Melastomataceae and emphasizing the environment potential role in the development of such a structure.

Brazil is recognized as the $17^{\text {th }}$ country in megadiversity of plants, with 17,630 endemic species among a total of 31,162 Angiosperms [1]. The focus in the Brazilian Cerrado Biome (Brazilian Neotropical Savannah) species is justified because this Biome is recognized as a World Priority Hotspot for Conservation, with more than 7,000 plant species and around 4,400 endemic plants [2-3].

The Brazilian Cerrado Biome is a tropical savannah-like ecosystem that occupies about 2 millions of $\mathrm{km}^{2}$ (from 3-24 ${ }^{\circ}$ Latitude $\mathrm{S}$ and from $41-43^{\circ}$ Longitude W), with a hot, semi-humid seasonal climate formed by a dry winter (from May to September) and a rainy summer (from October to April) [4-8]. Cerrado has a large variety of landscapes, from tall savannah woodland to low open grassland with no woody plants and wetlands, as palm swamps, supporting the richest flora among the world's savannahs-more than 7,000 native species of vascular plantswith high degree of endemism $[3,6]$. The "cerrado" word is used to the typical vegetation, with grasses, herbs and 30-40\% of woody plants [9-10] where trees and bushes display contorted trunk and branches with thick and fire-resistant bark, shiny coriaceous leaves and are usually recovered with dense indumentum [10]. According to [8], natural fires and anthropogenic fires coexisted for thousands of years and, together with the seasonality of 
rainfall and the poverty of nutrients in the soil are the responsible for the phytophysiognomy of Cerrado.

One of the first systematized studies of Cerrado Biome was the one done in Lagoa Santa, Minas Gerais State, around the year of 1892, by Warming [11], who described the place in aspects of soil, temperature, water precipitation and vegetation. When he [11] described the vegetation of flat grassland, he emphasized the thickness and toughness of Poaceae and Cyperaceae leaves and the abundance of perennial herbs or subshrubs with large lignified underground organs, multiple shoots growing from an underground stem and xeromorphic characteristics, as dense pilosity, coriaceous leaves positioned in acute angle and with reduced size. His [11] conclusion was that the dryness of the air, the harsh and dry clay soil and eventually, the fire occurrence, were responsible for these xeromorphic features of the plants.

Since then, a lot of work has been done to explain some contradictions such as the abundant flowering and budding and no signs of turgor loss during the dry season [10]. In [12] linked the plants physiognomy with the occurrence of fire and proposed an ecological classification of the Cerrado plants: plants which survive only during the rainy season, without any bud or leaf during the dry season (winter); grasses with superficial roots, like Echinolaena inflexa (Poir.) Chase and Tristachya chrysothrix Nees, which wither when the water is gone in the superficial soil; bushes and small trees with deep roots (up to 11 meters), usually green during all the dry season, which represent the typical vegetation. Leaves of the specimens observed [12] never closed completely their stomata: Kielmeyera coriacea Mart., Annona coriacea Mart., Annona furfuracea A.St.-Hil., Palicourea rigida Kunth, Stryphnodendron obovatum Benth.(syn=S. barbatimao), Didymopanax vinosum (Cham. \& Schltdl.) Marchal, Byrsonima coccolobifolia Kunth, Cocos leiospatha Barb. Rodr., Echinolaena inflexa (Poir.) Chase , Andira laurifolia Benth., Anacardium pumilum Walp., Neea theifera Oerst. and two species of Erythroxylon genus. In [13], perennial species with deep roots were associated to the ability of regenerating the aerial parts after a long dry season or after fire; these type of plants were designated as periodics, because they reduce or eliminate their leaves and branches during the winter, when the available water is rare at the soil surface.

The work [14] indicated that Cerrado soils are deep, with pH between 4,0 and 5,5 (acid) and connected the xeromorphic features in trees to nitrogen deficiency, because the studies done in Cerrado showed that water was not a limiting factor to these plants. In [15] it was added another important aspect to explain xeromorphic features in Cerrado plants: the high levels of aluminum would be a principal cause of mineral deficiency which would affect all Cerrado vegetation. Soils under Cerrado are usually poor, acid, well drained, deep, and show high levels of exchangeable aluminum [16-17]. The soil of the low grassland in the area of the old Experimental Station of hunting and fishing Emas (Pirassununga, São Paulo State) can be as deep as 20 meters and the groundwater is at 17-18 meters below the surface; only the first one to 1.5 meters dries during the winter and roots of at least one tree (Andira sp.) can reach the deepest groundwater; a shrub species, Anacardium humile A. St.-Hil., with aerial parts reaching 0.5 meters high, can have roots with over three times its shoot length [12]. The underground systems of roots and stems are so big in some species, such as in Andira laurifolia Benth., that in [11] it was called an "underground tree". Low concentration of nutrients in the leaves of 
native species is related with the low concentration of nutrients of the dystrophic soils [18] and the floristic composition and dominance of species is a reflection of it. Cerrado plants absorb significant amount of aluminum and when the leaf concentration is over $1,000 \mathrm{mg} \mathrm{Kg}^{-1}$ the species is referred as Al-accumulative [19]. It is still unknown if this amount of aluminum have any physiological or structural significance in the metabolism of the native plants [20], but the translocation of this element is showed by the presence of aluminum in the phloem and other metabolically active tissues of leaves and seeds and there are at least two plants which cannot survive in medium without aluminum: Miconia albicans (Sw.) Steud. (Melastomataceae) and Vochysia thyrsoidea Pohl (Vochysiaceae), woody species from Cerrado [18, 20]. Another curious aspect about Cerrado plants is that there are species that only live in calcareous or acid soils and there are also those which are indifferent to soil fertility [21].

The occurrence of wildfire is a common and important factor to be considered in the studies of this Biome vegetation, because it selects structural and physiological features of the plants and act as a renewal element [22]. In [13] were described some strategies which could help the perennial smaller plants to survive fire; during the dry season, some of them reduce or eliminate leaves and shoots and rely on their extensive underground system to re-sprout the aerial system after the dry season or after fire. As examples of fire resistance, in [13] were quoted the plants studied by [11], Andropogon villosus f. apogynus (Hack.) Henrard (Poaceae), Scirpus warmingii Boeckeler, Scirpus paradoxus (Spreng.) Boeckeler and Rhynchospora warmingii Boecheler (Cyperaceae), as well as Aristida pallens Cav., explaining that these plants have buds in the base of the aerial system well protected by some layers of sheath blades; the old ones are more external and will burn first, always protecting the newest ones and the internal buds.

An extensive review of the morphological and ecological studies is given in [10], whose author considered the Cerrado a great environment for scientific discussion and discuss the vegetation in a broader perspective, and in [23-24], whose author is more centered in anatomical aspects of Cerrado species.

Although the Cerrado Biome is a hotspot for the conservation of global biodiversity which shelters species fully adapted to survive under harsh conditions of soil and climate of this savannah-like environment [2], only $30 \%$ of its biodiversity is reasonably known [25]. Considering that the open environments in this Biome are subject to high luminosity and seasonal variation in the rain, how do plants react to adapt themselves? Considering that fire is also a natural event during the dry season, is there any morphological and/or anatomical variations developed to survive? Considering that the ground water level of some areas can vary in a high degree among the two seasons, how do plants manage to survive? Some of these questions will be addressed and data about it will be shown.

\section{Methodology}

In order to perform studies about morphology, anatomy or cell biology, as well as when the flora is been studied, it is usual to collect control or testimony material to guarantee species 
identification and further studies [26]. Vegetative and flowering plant branches are collected, pressed, dried and deposited as control material at some Brazilian Herbaria, following usual techniques [27]. The previous identification of the species is done with the aid of a stereomicroscope, identification keys and specialized literature [28-38]. After previous identification, plant vouchers stay preserved to the study of a taxonomist specialized on the family and for future references, including of the place of occurrence, under a specific number of the principal collector, normally not only in one Herbarium (duplicates are usually distributed).

When studying the leaf anatomy, histological samples are obtained from visually healthy green and completely developed leaves, usually from $3^{\text {rd }}$ to $5^{\text {th }}$ node, of pre-identified species; samples can be or not submitted to different fixatives and paraffin embedding medium [39] before slicing it to be studied under an optical microscope (light microscopy). Cell samples in tissue for ultrastructural studies can be smaller pieces of the aimed organ submitted to a fixative and post-fixed in heavy metals in the dark, followed by in-block staining [40]. Later, plant pieces are dehydrated and slowly embedded in a harder medium (epoxy or epon resin), to be sliced for observation. Semi-thin sections can be obtained with an ultramicrotome using glass knives, stained and analyzed under the optical microscope in order to localize the cells in the tissues; ultra-thin sections of the same material are obtained with a diamond knife, collected in copper grids and analyzed under a transmission electron microscope (TEM), with or without any additional staining. To be studied under a scanning electron microscope (SEM), sections of the plant are also fixed and post-fixed as indicated for TEM analysis [40], with some modifications because of plant characteristics, but the use of control pieces [41] is necessary to avoid interpretation errors. After that, fixed pieces are dehydrated in ethanol or acetone solution and critical point dried in the proper device, attached to a stub and gold sputtered to be observed under SEM [40].

\section{Morphology, histology and cell biology studies}

Morphological studies are used to identify and characterize the plant species in taxonomy, but it is also important to understand the behaviour of plants in nature. The first hint on the function is based on the external morphology of the organs. Different plant species can be very alike in habit and vegetative morphology, especially in some plant families as Amaranthaceae, which rely upon some flower details to be truthfully identified, demanding a highly specialized work [33-38, 42-44].

Anatomy and cell biology studies aim to describe and understand the species organs and cells and help taxonomy to define affinities and parental relationships among plant groups. When combined with histochemical analysis they can lead to a better understanding of the cell, tissue or organ function and the interaction between the plant and its environment.

It is usual, in plant structural studies, to bear a description of the aimed plant or organs of interest, assuming that the function is already explained enough by the function of the organ in the plant or by previous researches. As results are subject to interpretation and there are some variables to be considered, it is not usual to connect the structure to the function. 
However, in the Cerrado species case, since the first studies there is an attempt to explain the structure and relate it to the unique environmental conditions, which was detailed in the introduction of this work, helping to give a broader significance to the structure.

Studying the so called xeromorphic features of three leaves, [14] concluded that they could be explained by the soil oligotrophic conditions, given raise to the theory of oligotrophic scleromorphism: the mineral elements deficiency would be the main responsible for the plant characteristics, by limiting its grow; the carbohydrate accumulation is then converted in deposits of thick cuticle, thicker cell walls, wax deposits over the epidermis and other scleromorphic features. High level of aluminum in Cerrado soils, another cause for the oligotrophic scleromorphism [15] is considered the main responsible for the acidity of Cerrado soils [45]. Through the study of eleven Cerrado plants, [46] it was indicated the constant presence of fungi over its leaves, mostly on species without epicuticular wax, and connected this outermost layer over the cuticle layer to environmental adaptation, as protection against any fungus hypha.

Sclerenchymatous elements, fibers and sclereids are distinctive structural features in vegetative organs of Cerrado plants, and the presence of gelatinous fibers is frequent, associated or not with the tension wood; besides, it is also constant the impregnation of silica and siliceous bodies, not only in Poaceae and Cyperaceae species, but also in leaf and stem epidermis, roots and xylopodium of Brasilia sickii G. M. Barroso (Asteraceae) [23-24]. In epidermis, [24] silica is connected to the protection against excessive transpiration and as a defense mechanism against fungi. In [24], author also explained why the aperture or closure of stomata can be slower in Cerrado plants: it would be due to the thickening of the guard cells walls of a stoma, which can be impregnated with lignin, as in Ouratea spectabilis (Mart. ex Engl.) Engl. or have silica incorporated, like in Esterhazya splendida J. C. Mikan, B. sickii and Casearia grandiflora Cambess.

Amaranthaceae family is considered a good representative of the herbs and subshrubs of Cerrado due to its morphology and adaptations that promote survival in adverse conditions (drought and fire), such as tuberous or woody roots, xylopodium, herbaceous or subshrub habit, dense pubescence in aerial portions, senescence of shoots and leaves during the driest season, dependence on rain or fire to re-sprout and/or flowering, fruiting followed by wind dispersion, thick cuticle on epidermis and $\mathrm{C}_{4}$ photosynthetic metabolism [37, 47-48]. The knowledge of the reproductive structures in Amaranthaceae Brazilian species is mostly restricted to the obtained during floristic survey and with taxonomic purpose, with few additional studies of reproductive structures, such as [49], who studied the flower vascular pattern in Pfaffia jubata Mart., Gomphrena macrocephala A. St.-Hil. and Froelichia interrupta (L.) Moq. and [50], with the study of pollen from Cerrado species, helping to understand the phenology of them through the analysis of herbarium species.

In this section, some morphological, histological or cellular aspects of reproductive and vegetative (aerial and underground) organs will be exemplified, discussing the aspects related to the environment where these plants grow and survive and to the function in the plant species, whenever possible. 


\subsection{Reproductive organs - Flower, fruits and seeds}

Amaranthaceae flowers are generally small and densely clustered in terminal or axillary inflorescences (figure 1), pollinated by the wind or by insects, with self-pollinating or outcrossing [51]. Due to the hairy perianth, small and dry fruits or seeds, the dispersion is usually done by wind or water [51]. In some genus, small seeds fall from the parent plant and germinate only when the site is again disturbed; seeds can be, also, eaten and dispersed by browsing animals [51].

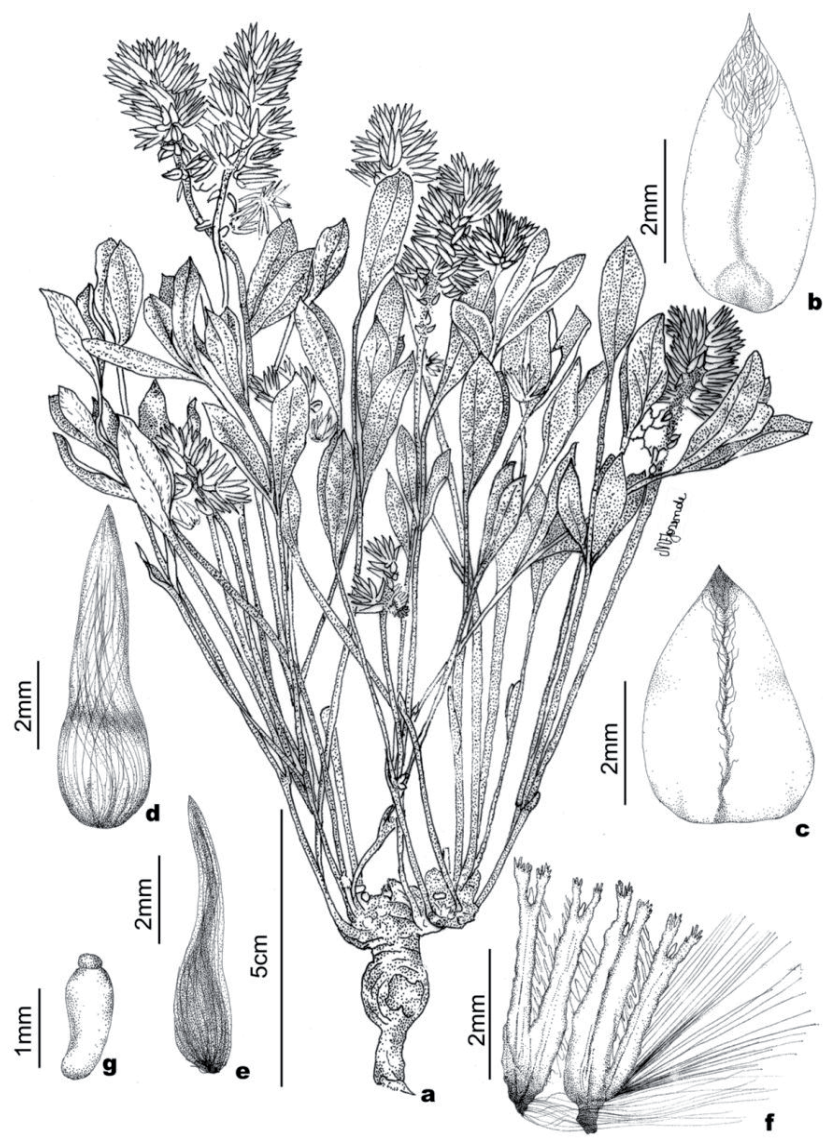

Figure 1. Pfaffia jubata Mart. a: habit; b: median bract; c: lateral bract; d-e: sepals; f: staminal tube; g: ovary (Hatschbach et al. 53625, MBM). Reproduced from [37] with permission of Hoehnea publisher. The species was considered a good representative of Amaranthaceae family: habit from herb to subshrub, 0.10-0.20 m high, stems erect, densely villous and woody root. Leaves have the upper side densely villous and lower side tomentose. Inflorescence is a spike, isolated, simple, terminal, with ferruginous trichomes. 
Brazilian species of Celosia, Chamissoa and Amaranthus have circumscissile capsule fruits, with only one seed in the two last genera and more seeds in the first one; capsules are surrounded by the perianth and parts of the androecium and gynoecium, except in Amaranthus where the filaments are free and there is no staminate tube [52]. Dehiscence can be median (Amaranthus) or semi basal (Celosia) and dispersal is probably done by autochory [52], although [53] considers the accidental endozoochory more probable in Amaranthus case, because ruminants usually eat Amaranthus inflorescences.

Fruits of Alternanthera, Pfaffia, Gomphrena, Blutaparon, Achyranthes, Cyathula and Pseudoplanta$g o$ are one-seeded capsules with two valves included in the perianth sepals which are glabrous to hairy or spine-like; these fruits can carry part of the androecium and gynoecium and sometimes the perianth displays external bristle tufts or modified bracts [34-35, 52]. Wind seems to be responsible for the dispersal of Alternanthera, Pfaffia, Gomphrena and Blutaparon fruits because of the hairiness of the perianth, which presents long trichomes; species of Froelichia, Froelichiella, Pfaffia and Gomphrena genera from open grassland have their fruit easily dispersed by the wind [34-35, 52].

In [54] wind dispersal of fruits in species which occur in Cerrado regions that were affected by fires, mostly Gomphrena macrocephala associating the natural fire with the easier dispersal of its fruits and seed germination. The passage of fire burns grasses and help dispersal of the G. macrocephala, G. pohlii Moq. and G. virgata Mart. fruits; fire also promotes the dehiscence of the fruits, leaving the seeds nearer to the soil $[42,55]$. The maturation and dispersal of fruits is exemplified in G. arborescens L.f. (figure 2), a native Cerrado plant which behaves the same way of G. macrochepala [54]: the inflorescence opens for pollination and closes after that due to a growth of its bracts for the maturation of the fruits; after that, the shoot inclines towards the soil and the inflorescence structure reopens to release the dispersal units in the soil, formed by the seed and parts of the perianth, until the wind carries it. The same phenomenon was observed in Pfaffia argyrea Pedersen, P. cipoana Marchior. et al., P. denudata (Moq.) Kuntze, P. elata R. E. Fr., P. hirtula Mart., P. jubata Mart. P. minarum Pedersen, P. rupestris Marchior. et al., $P$. sarcophylla Pedersen, $P$. siqueiriana Marchior. et al, $P$. townsendii Pedersen, $P$. tuberculosa Pedersen, P. velutina Mart. and Froelichiella grisea (Lopr.) R.E.Fr. all Cerrado species which occur in areas subject to burning $[37,55]$. Froelichia has one-seeded nutlet involved by parts of the gynoecium and androecium, partially because of the connated perianth and presents a wing structure densely hairy which favours the wind dispersal [34, 52].

Although Alternanthera and Blutaparon genera fruits are usually wind dispersed, Alternanthera pungens Kunth have its perianth highly modified, presenting uneven sepals, with the outer two sharply pointed, which can help its adhesiveness in animal skin or fur to be dispersed [52]. The same occurs with Achyranthes and Cyathula genera, which fruits are dispersed by animals through adhesiveness structures [53]. Achyranthes two perianth lateral bracts are thorn-like, the same as in Pseudoplantago friesii Suess [52]. Cyathula have a set of uncinate bristles which can be considered sterile flowers and play a special function in helping the fruit dispersal attached to skin or fur of animals, a phenomenon called epizoochory [52]. 

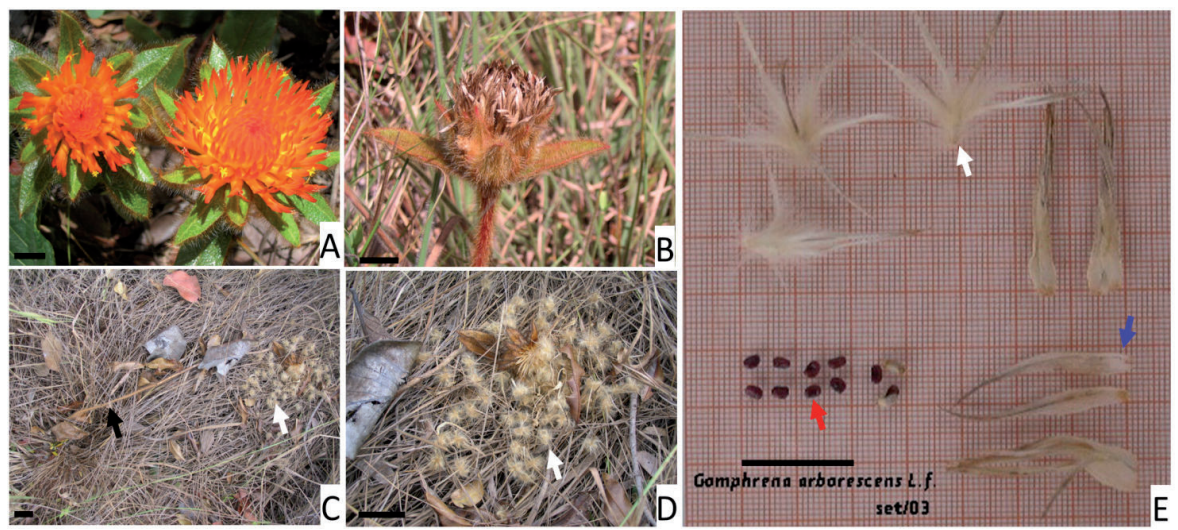

Figure 2. Fruits of Gomphrena arborescens L.f. are dispersed by the wind. The inflorescence opens for pollination (A) and closes after due to a growth of its bracts (B) for the maturation of the fruits; after that, the shoot (black arrow) inclines towards the soil (C) and the infructescence structure reopens to release the diaspores (white arrow in C, D, E) in the soil, formed by one seed (red arrow in E) and parts of the perianth (blue arrow in E), until the wind carries it. Scale bars: A-E: $2 \mathrm{~cm}$

Amaranthaceae species are well adapted to Cerrado environment and some species display different strategies to survive during the markedly seasonal climate of the Cerrado Biome [47]. Using only data obtained about perennial species, an interesting case is the aerial life cycle of Froelichiella grisea, which is endemic of the rocky fields of Chapada dos Veadeiros, Goiás State [34]; this species was registered during the onset of the flowering stage in the field, almost after two years of searching for it, only 20 days after a fire that burned out the vegetation (in August, during the dry season); Gomphrena lanigera Pohl ex Moq. also was found only at the same day, at the fruiting stage, revealing an even faster life cycle of the aerial parts [48, 57]. On the other hand, the species Pfaffia townsendii and G. hermogenesii J.C. Siqueira were found in the same region all year round; whilst the first one was always bearing flowers (it is a well-branched shrub that stands out in the middle of the rocks), the second one was usually found in the vegetative stage, more or less hidden among the surrounding Gramineae (=Poaceae) and Cyperaceae; only after the fire grazed all the grasses of the area, G. hermogenesii re-sprouted its aerial organs and was found in the onset of the flowering stage $[48,57]$. Another species, G. arborescens is usually found at bloom time at RECOR/IBGE and at the Olympic Center of Universidade de Brasília, in Brasília, Federal District, during the rainy station (from November to April) and at vegetative stage from August to October (during winter); in this 0.5 meter high species, leaves were always attached to the shoot at the same time as the flowers and fruits, although in the end of the fruiting stage, some or all the shoots bearing fruits can dry out, in order to release the fruits [58]. Another species, G. virgata, found in the same locations than G. arborescens, reaches $2.0 \mathrm{~m}$ high and is found at vegetative stage from March to July (middle of the dry season) and fruiting goes until September (end of the winter); in the beginning of the bloom period, leaves enter in a senescence process and are detached from the shoot; after dispersing seeds, its aerial parts also dry out, re-sprouting around March (near the end of rainy 
season) [58]. Found only at the Olympic Center, G. pohlii develops its aerial organs up to 1.8 $\mathrm{m}$ high from August to November, starting the blooming period in December and finishing fruit dispersion around April, drying out its aerial portions during the winter [58].

As an agent of perturbation in the vegetation of Cerrado, fire can produce variable effects in the flowering and fruiting patterns: whilst flowering is more intense in the herbaceous layer after a fire breaks out, the same phenophases are not affected in trees and shrubs [59]. A thicker pericarp in dry fruits may provide greater protection for seeds, acting as a barrier against high external temperatures, such as in Kielmeyera coriacea winged seeds inside dry fruits [60]. Fire increases the dehiscence in anemochoric species [54,60].

Would be necessary more research in order to understand not only the structures of reproductive organs, but also describe the relation among flowers and its pollinators in Cerrado species and to understand the phenology of the species, which have different strategies to survive natural and eventual events, since dropping leaves during the flowering/fruiting phase, recycling all aerial parts after completing the fruiting phase, among others.

\subsection{Vegetative structures of Amaranthaceae and Melastomataceae species}

During the study of Brazilian Amaranthaceae species some morphological characteristics stood out in Cerrado species: well developed subterranean systems with xylopodium, high level of endemism and hairy stem, leaves, flowers and fruits [34, 37, 47, 56], which indicates adaptations of these plants to the environment. Xeromorphy and scleromorphy are common features in leaves of Cerrado species [61]. Although the two terms describe similar morphology results, a xeromorphic plant is adapted to withstand drought and a scleromorphic plant is the result of other limiting factors to its growth instead of water, for instance a restricted nutrient intake [14] or aluminum toxicity [15]. Some aspects of the plants can be genetically determined, developed as a selective advantage, such as the development of xylopodia in Clitoria guianensis Benth. and Calliandra dysantha Benth. [62], both Cerrado plants.

Scleromorphism is precocious in all organs, especially the vegetative ones [24], which is why the most aimed organs to study structure are leaves, stem and roots, although the identification of a plant is usually obtained by the study of its reproductive organs. Field observations, morphological, anatomical and cellular data on aerial structures of Amaranthaceae and Melastomataceae species will be emphasized in order to improve the understanding of the surviving strategies used by some species of these families [35, 47, 61].

\subsubsection{Leaf structure}

Leaf anatomical traits are useful to infer adaptations to a specific environment [63-64] and are good predictors of performance [65] because of their common and strong relationships with functional parameters such as photosynthesis, leaf nutrient content and radial growth [66-69]. Studies with Macairea radula (Bonpl.) DC. and Trembleya parviflora (D. Don) Cogn. (Melastomataceae) showed quantitative anatomical plasticity in different environments [61]: plants on open flooded area of palm swamp had significantly smaller values of specific leaf area and significantly higher values of leaf mesophyll thickness when 
compared with leaves partially shaded on non-flooded soil of the Cerrado sensu stricto, indicating that the former are smaller and thicker than the latter. Quantitative plasticity may also appear in the leaf flush as an influence of seasonality. Leaves which flushed during dry or wet season, in Gochnatia polymorpha (Less.) Cabrera (Asteraceae), showed statistically significant differences in the cuticle, mesophyll and abaxial epidermis thickness, stomatal size, stomata and trichomes density, indicating a probable water-status control and an adaptation to seasonality of rainfall in the Cerrado [70]. Furthermore, in [70] the authors emphasized a positive correlation between the increase in the number of trichomes and stomata density in the dry season, and suggested that this relationship would promote a highest control over stomatal conductance and transpiration.

Plants of different physiognomy of Cerrado showed that leaves are hypostomatic in most of the species, whilst there are also amphistomatic species [61,71-73]. Stomata only on the abaxial surface are an advantageous trait for plants on low relative humidity and high temperature environment because it could reduce the loss of water vapour as the temperature on the abaxial side of the leaf is lower [74-75]. On the other hand, stomata on both surfaces makes it easier the intercellular diffusion of $\mathrm{CO}_{2}$ in mesophyll of thicker leaves [76] and amphistomatic leaves are characteristics of plants living in high-light environments and with high photosynthetic capacity [74]. The same species can display stomata on both or only on one leaf surface in response to the light intensity under which they are grown, which can be related with leaf thickness, photosynthetic capacity and maximum stomatal conductance [75]. Leaves of the same species which were grown on high-light environment can be amphistomatous, thicker and with higher rates of photosynthesis, stomatal conductance for $\mathrm{CO}_{2}$ uptake and loss of water vapour, whilst leaves of plants grown under low-light intensity are hypostomatous and show lower values for the same variables [74-76], demonstrating the plasticity of this feature and its influence on the hydric balance and gas exchange of the plants.

Ericaceae species Gaylussacia brasiliensis (Spreng.) Meisn. (figure $3 \mathrm{C}$ and 3E), and species of Myrtaceae [77] and Melastomataceae [61] of cerrado sensu stricto and palm swamps have epidermis cells that present simultaneously evaginations of protoplasm and invaginations of the external periclinal cell wall (figure 3A-D). In frontal view the cell walls are sinuous and evagination points are usually shinier (figure 3E-F). Although the function of this feature is unproven, similar structures were found in Drosera [78] and named miniature papillose processes, which would be functioning as sensors for mechanical or chemical stimuli.

Emergences are structures of mixed protoderm and ground meristem origin, and are generally found in Melastomataceae leaves (figure 4). These structures are related with the vascular system and ultrastructural and histochemical analyses of the cell walls revealed micro channels permeable to water and nutrients, indicating that these structures are related with the transport of substances and may absorb or exude solutions [61, 79-80].

Phenolic compounds are regarded as protective against the incidence of UV-B radiation and could act as filters or antioxidants [81-84]. These secondary metabolites are also considered inhibitors of herbivory which, along with radiation, function as a stimulator in the biosynthesis of phenolic compounds [85]. Phenolic compounds are very common in leaves of Cerrado plants of diverse physiognomy such as palm swamp, a flooded and open soil, in a dry forest 

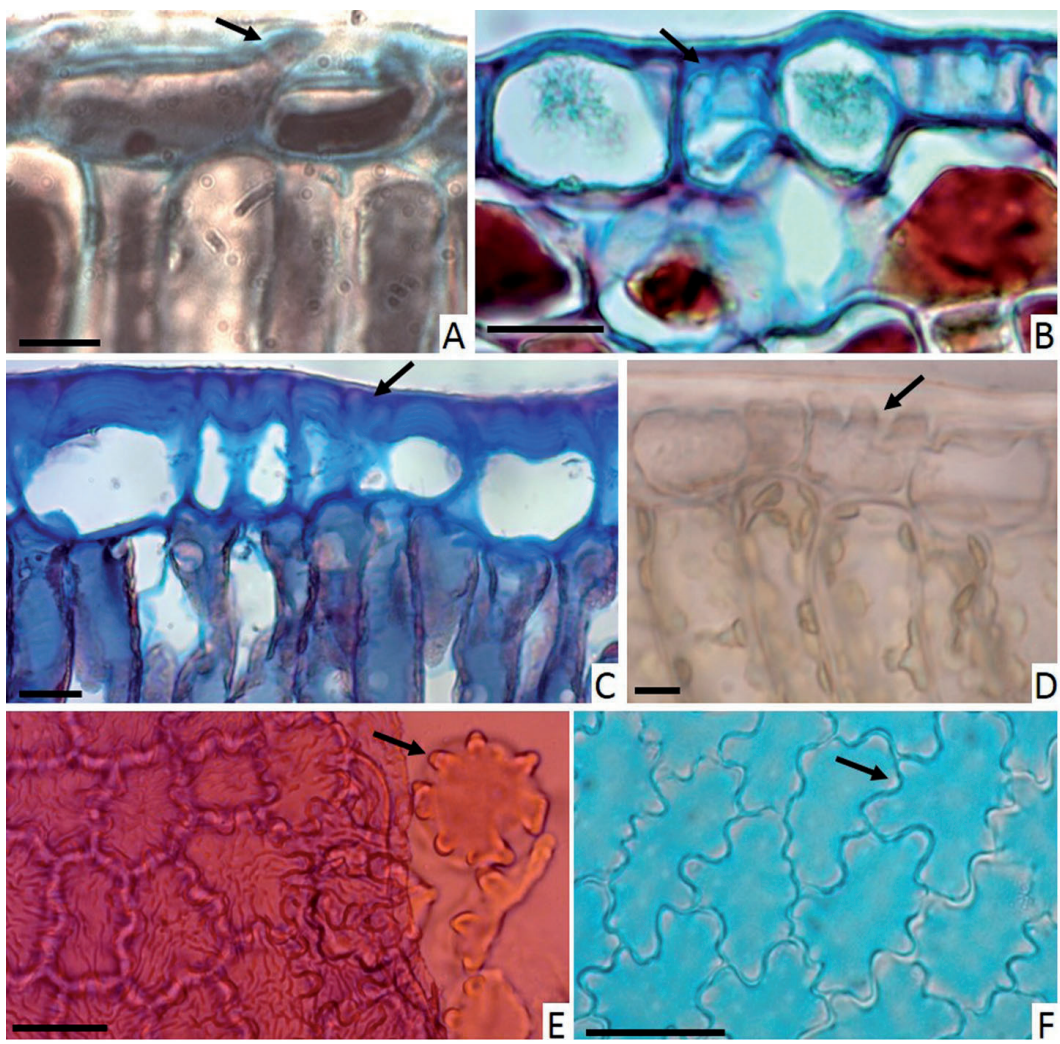

Figure 3. Leaf epidermis with evaginations and invaginations of external periclinal cell wall. A-D: cross section; E-F: frontal view. A: Myrcia cordifolia DC. (Myrtaceae). B: Gomidesia pubescens (DC.) D. Legrand (Myrtaceae). C, E: Gaylussacia brasiliensis (Spreng.) Meisn. (Ericaceae). D, F: Lavoisiera bergii Cogn. (Melastomataceae). Arrow show evagination points in dissociated of epidermal cells (E) and shiny dots in frontal view (F). Scale bars: A-D: $20 \mu \mathrm{m}$, E-F: $50 \mu \mathrm{m}$.

on limestone outcrops or in open areas of Cerrado [26, 61, 73], where the leaves are exposed to high irradiance and high herbivory or fungi infection.

Although the photosynthesis is highly dependent on structural and ultrastructural coordination in leaves, the environment is responsible for the relative abundance of a determined subtype of the $\mathrm{C}_{4}$ pathway [86]. The $\mathrm{C}_{4}$ photosynthesis pathway evolved in a great diversity of Kranz anatomy forms, biochemical routes and dimorphism of chloroplast ultrastructure [87-89] and is broadly dispersed among Angiospermae plants, including in the Amaranthaceae family [90-91].

The parenchyma bundle sheath and the mesophyll cell arrangement are the most usual anatomic pattern to determine the $\mathrm{C}_{4}$ photosynthesis pathway [92]. However, the high degree 


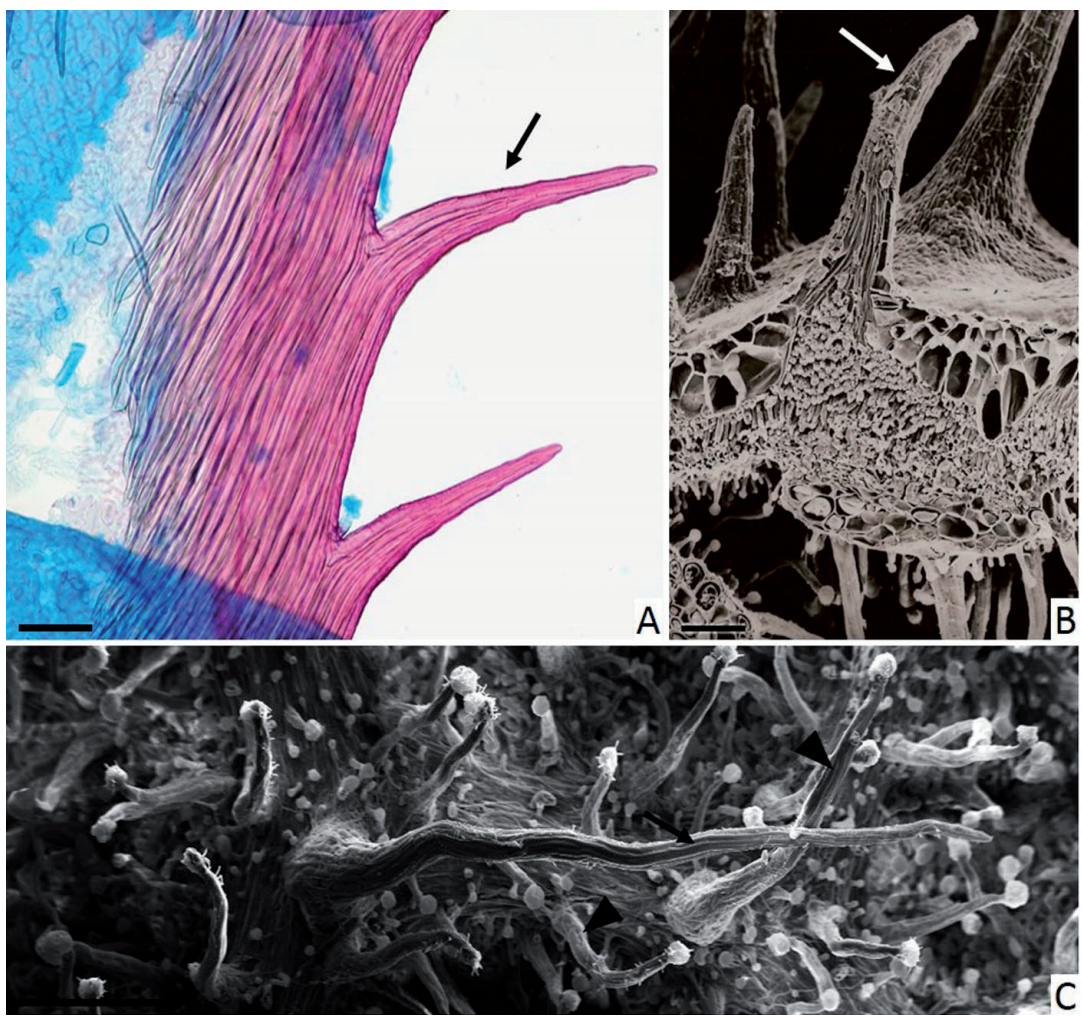

Figure 4. Leaf emergences in Melastomataceae. A: Non-glandular emergence (arrow) in margin of Lavoisiera bergii Cogn. B: Non-glandular emergence (arrow) in adaxial surface of Macairea radula (Bonpl.) DC. C: Non-glandular (arrow) and glandular (arrowhead) emergences in abaxial surface of Macairea radula Scale bars: $100 \mu \mathrm{m}$

of evolutionary convergence does not guarantee a unique pattern at biochemical or cellular and subcellular levels [86]. The structural type of leaves (Kranz or non-Kranz), the chloroplasts position, the absence or presence of stacked disks (grana) in the thylakoid membranes of chloroplasts and the number of mitochondria are important characteristics to know the photosynthetic metabolism of a plant species $[89,93]$. At ultrastructural level, number and concentration of chloroplasts, mitochondria and peroxisomes in the bundle sheath cells are the most reliable criteria to determine the photosynthetic capacity of a plant [94]. However, recent studies showed that the $\mathrm{C}_{4}$ photosynthesis can operate by dimorphic chloroplasts located in different regions of the same cell, as demonstrated in Orcuttia sp. and in Borszczowia aralocaspica Bunge and Bienertia cycloptera Bunge [87,95-97]. This way, the ultrastructural study of leaves can be a key element to understand the plant metabolism.

Since the first works, leaf anatomical studies done in Brazilian Amaranthaceae species showed a well-developed vascular bundle in Gomphrena and Froelichia genera, but not in Alternan- 
thera and Pfaffia genera [26, 98-101]. Intracellular studies are rarer [56, 102-103]. In [103] it is showed a gradual change in the stacked thylakoids of dimorphic chloroplasts in Gomphrena macrocephala, G. prostrata Desf. and G. decipiens Seub. connecting it with the NADP-ME subtype of $\mathrm{C}_{4}$ photosynthesis pathway, which was the same preliminarily observation done in $G$. arborescens [56]. Pfaffia jubata displays the same type of chloroplasts in different leaf tissues, indicating the operation of the $C_{3}$ pathway of photosynthesis [102]. In [103] are described dimorphic chloroplasts in G. scapigera Mart. leaves which ultrastructure was considered compatible with NADP-ME subtype of $\mathrm{C}_{4}$ photosynthesis. These results are coherent with the ones showed in Australian Gomphrena species: G. celosioides Mart., G. globosa L., G. conica (R. Br.) Spreng., G. brachystylis F. Muell., G. brownie Moq., G. flaccida R. Br., G. canescens R. Br. [93].

Leaves of 13 Amaranthaceae species-Alternanthera brasiliana (L.) Kuntze, A. paronychioides St.Hil, Froelichiella grisea, Gomphrena arborescens, G. hermogenesii, G. lanigera, G. pohlii, G. prostrata, G. virgata, Hebanthe eriantha (Poir.) Pedersen, Pfaffia glomerata (Spreng.) Pedersen, P. gnaphaloides (L.f.) Mart. and P. townsendii were studied in order to understand their metabolic pathway of photosynthesis $[47,56]$. All the species are native to Brazil and occur in the Cerrado Biome; six of them are endemic to Brazil and one is endemic to the Brazilian Cerrado Biome [38, 48]. All leaves are hairy (trichomes are rarer in Alternanthera species), amphistomatic (except Pfaffia townsendii), have one cell thick epidermis with stomata more or less leveled to the surrounding epidermal cells and dorsiventral mesophyll (except F. grisea, which has isobilateral mesophyll) with collateral bundles. All six Gomphrena species have thick-walled parenchymatous bundle sheath and organelles ultrastructure compatible with the operation of NADP-ME subtype of $\mathrm{C}_{4}$ pathway of photosynthesis. Whilst G. pohlii and G. virgata have a more classical type of Kranz anatomy (figure 5) [47], G. arborescens, G. hermogenesii, G. lanigera and G. prostrata have the same type of Kranz anatomy found in most Gomphrena species [93, 98, 102-105], classified as "Gomphrena type" [89] but all share dimorphic chloroplasts (figure 6) [47]. Alternanthera species presented variable anatomy, with organelles positioned towards the vascular bundle in A. paronychioides and in the peripheral position in A. brasiliana bundle sheath cells. The first Alternanthera species was characterized as a $\mathrm{C}_{3}-\mathrm{C}_{4}$ intermediate species [106] based on its leaf anatomy, $\mathrm{CO}_{2}$ compensation point and activity of key photosynthetic enzymes, but the authors did not mention stomata on both epidermis leaf surfaces, which is considered another fundamental feature to lower the $\mathrm{CO}_{2}$ compensation point [74]. Thus, the position of organelles in bundle sheath cells can be a key element in determining the intermediary metabolic type in Alternanthera species (figure 7) [47]. Froelichiella, Hebanthe and Pfaffia species have leaf anatomy and ultrastructure compatible with $\mathrm{C}_{3}$ metabolism [47]. Chloroplasts of the Kranz cells of $C_{4}$ plants usually have no grana, present little PSII activity and a larger amount of starch [107] whilst, in $C_{3}$ plants, the palisade cells show a larger amount of starch than the ones of the spongy parenchyma [108].

If the evolution of C4 metabolism is associated to the weather and ecological disturbance, is it possible to link some structural changes in leaves of Cerrado plant species to these evolution factors? The evolution of $\mathrm{C}_{4}$ metabolism in these Amaranthaceae species can be related to the development of amphistomatic leaves, associated with increased leaf thickness, thicker bundle sheath cell walls, fast lifespan of the aerial system and well-developed gemmiferous under- 
ground system as adaptation to an open shinny environment with seasonal rain and oligotrophic acid soil, at least partially. Species' survival in adverse environments can be achieved by the operation of $C_{4}$ photosynthesis and carbon accumulation [109], which is associated with high photosynthesis rate [74]; the accumulated carbon is stored and protected in the underground organs, explaining the energy source to re-sprout of Cerrado species. Although in [92] trichomes are believed to affect the gas exchange and leaf temperature, reducing the light incidence, Gomphrena arborescens developed a translucid tissue surrounding the large trichome bases, which allows the light to reach internal photosynthetic tissue [26], indicating that its trichomes can be more a restriction to herbivory than to reduce leaf temperature or light incidence, the same way as in G. pohlii and G. virgata [58]; another aspect shared by all Amaranthaceae Cerrado' species is the constant presence of calcium oxalate druses inside leaves and shoots $[26,47,57-58]$, which is considered a highly specialized way of sequester and immobilise calcium [110].

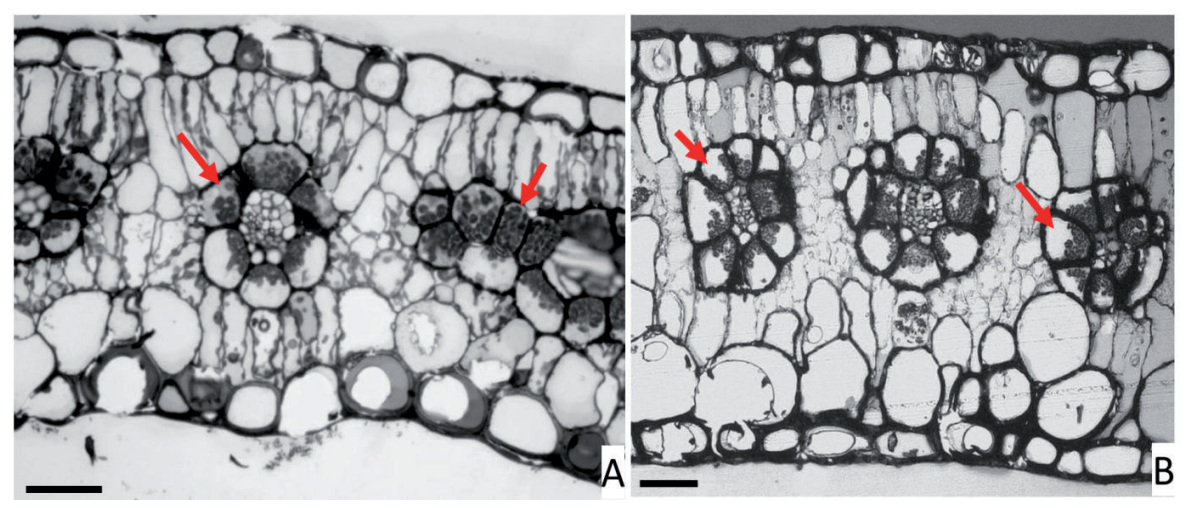

Figure 5. Gomphrena pohlii Moq. (A) and G. virgata Mart. (B) (Amaranthaceae) leaves in cross sections. Red arrow indicates bundle sheath cells with organelles positioned near the inner cell walls, towards the vascular bundle. Scale bars: $50 \mu \mathrm{m}$.

Large plastoglobuli were found in chloroplasts F. grisea, G. arborescens, G. hermogenesii, G. pohlii and G. virgata. According to [111], plastoglobule consists of an outer lipid monolayer containing neutral lipids and proteins/enzymes related to lipid metabolism; its dimensions vary from $30 \mathrm{~nm}$ to several micrometers. Plastoglobuli shape and size change during development and plastid differentiation, and under stress conditions, clustering of large groups of connected plastoglobuli were observed [111-112]. Lipid and protein storage inside the chloroplasts could support plants' fatty acid regulation, unsaturation and mobilization in response to the stress caused by biotic interactions, especially due to the presence of plastoglobulin among its proteins [111, 113]. Although higher plastoglobuli content in chloroplasts could be linked to plant senescence [114], this may not be the case of these Amaranthaceae plants because all leaf samples were visually healthy and green when collected. In G. hermogenesii leaves which were infected for some sort of septate endophytic organism (figure 8), 

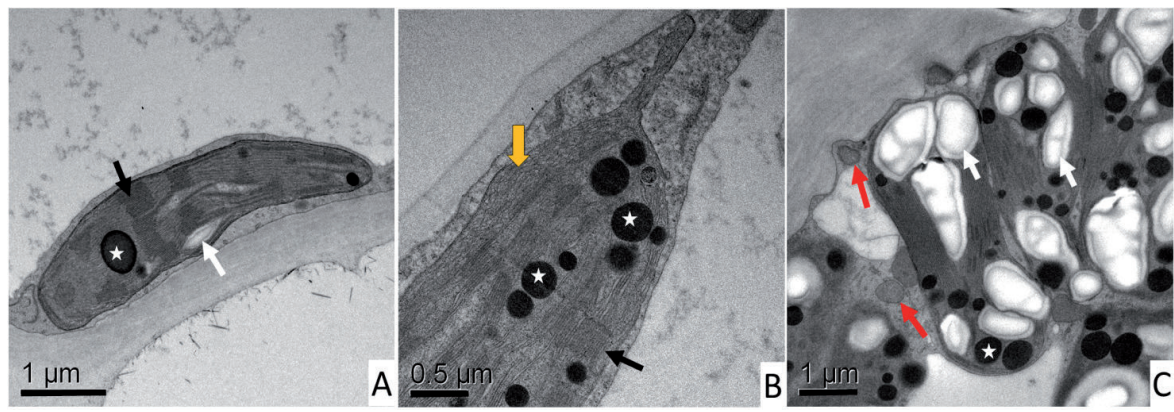

Figure 6. Dimorphic chloroplasts in Gomphrena species (Amaranthaceae) observed through an electron transmission microscope. A: Granal (black arrow) chloroplast of Gomphrena arborescens L.f. spongy parenchyma, with few starch granules (white arrow) and a large plastoglobule (white star). B: Granal chloroplast in G. pohlii Moq. palisade parenchyma, with well-developed peripheral reticulum (orange arrow) and large plastoglobuli (white stars). C: Organelles in G. arborescens bundle sheath cell, which are positioned towards the vascular bundle, with chloroplasts with no stacked disks (grana) of thylakoid membranes, but large amount of starch granules (white arrow), large plastoglobuli (white star), and mitochondria (red arrow). Scale bars: A, C: $1 \mu \mathrm{m} ; \mathrm{B}: 0.5 \mu \mathrm{m}$.
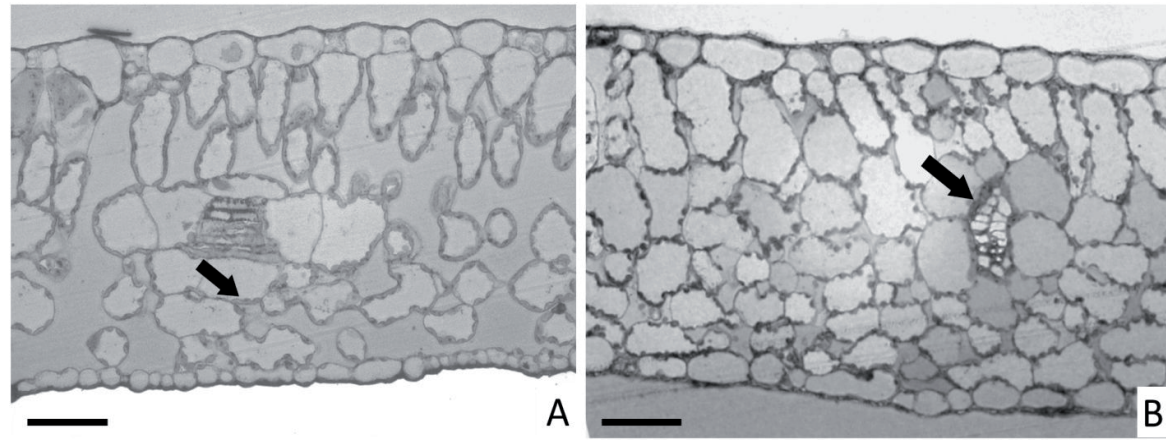

Figure 7. Leaf anatomy of Alternanthera species (Amaranthaceae) observed in cross sections. A: Alternanthera brasiliana (L.) Kuntze ( $\mathrm{syn}=$ A. dentata). B: A. paronychioides A. St.-Hil. $(\mathrm{syn}=A$. ficoidea). Black arrow indicates the bundle sheath cell with organelles near the outer cell wall in $\mathbf{A}\left(\mathrm{C}_{3}\right.$ species) and towards the vascular bundle in $\mathbf{B}\left(\mathrm{C}_{3}-\mathrm{C}_{4}\right.$ intermediary species). Scale bars: $50 \mu \mathrm{m}$.

when compared with non-infected leaves (figure 8), plastoglobuli were reduced in size, which suggests a mobilization of its content due to the interaction with this microorganism.

Leaf surfaces of some Cerrado species of the genus Gomphrena presented epicuticular wax crystals in platelet form, oriented in parallel [58], an aspect previously described only in Chenopodiaceae species. If these platelets are present only in Cerrado species, it could be explained as a way of immobilize the excess of carbohydrates produced by a species with high photosynthesis rates and limited growth - as preconized by the theory of oligotrophic scleromorphism [14]. Crystalloid wax projections were found on both leaf surfaces of Gomphrena arborescens, G. pohlii and G. virgata, as platelets distributed in different densities and 


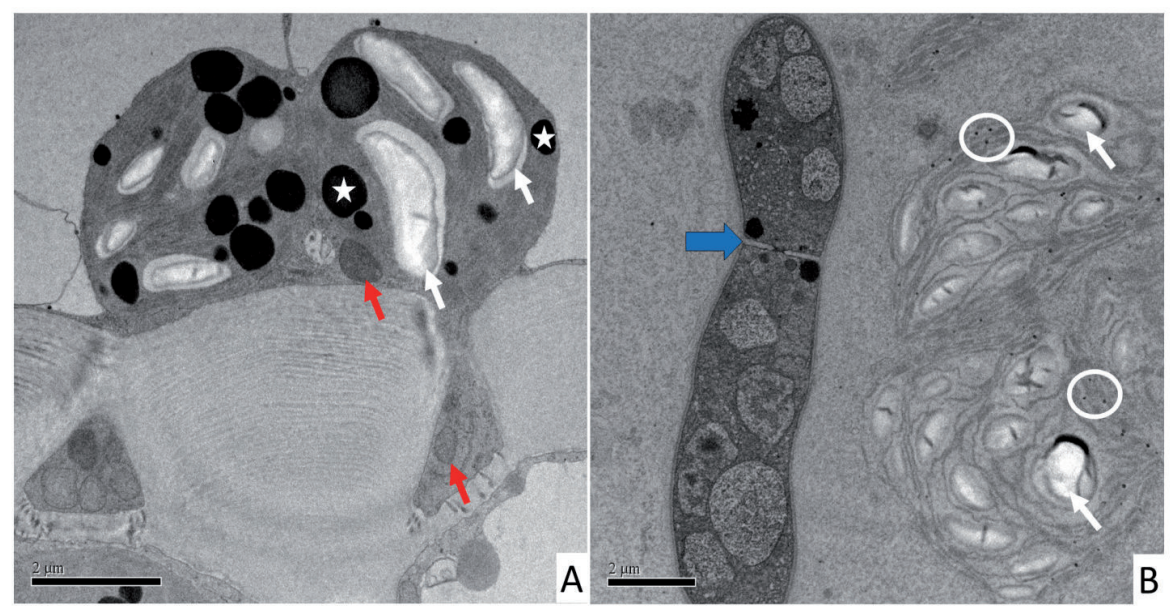

Figure 8. Chloroplasts in Gomphrena hermogenesii J.C. Siqueira bundle sheath cell. A: Non-infected sample show the chloroplast with starch (white arrow) and large plastoglobuli (white star); mitochondria (red arrow). B: Sample with a septate endophytic microorganism (blue arrow), shows that chloroplast's large plastoglobuli were mobilized (white circle in B) and the membrane system was disrupted, while starch (white arrow) was preserved. Scale bars: $2 \mu \mathrm{m}$.

patterns; epicuticular wax did not prevent the development of fungi hyphae on leaves of none of these three Cerrado native species; however, the development of such a structure should be one adaptation of the Cerrado species, because they present more platelets and ridges of epicuticular waxes in relation to G. globosa, an introduced species also studied [58].

There is much work to be done in order to understand all aspects connected to leaf function in Cerrado plants, because more than been the primary photosynthetic organ which produce carbohydrate for the plant, leaves also give place to biotic interactions (it is common to find fungi or insects larvae in leaves) which can affect the plant life, including the onset of the production of complexes chemical compounds of interest because of its biologic activity (alkaloids, tannins or other phenolic compounds, sterols, saponin).

\subsubsection{Root and stem structure}

Melastomataceae species are found in several physiognomies in the Cerrado, from well drained to periodically or permanently flooded soils [115], displaying anatomical features which give them the ability of survive in different environments. Species of the palm swamps with periodically flooded soils produce an aerenchymatous tissue in roots and stem during the primary and secondary growth [116]. During the primary growth of root and stem the tissue is a schyizolisigenous aerenchyma and schyzogen aerenchyma, respectively. During the secondary growth, root and stem develop phellogen from division of pericicle cells, deriving two cells types, one with square or rectangular shape (compact cells positive for suberin in histochemical test under light microscopy) and another cell with " $\mathrm{T}$ " shape (negative for suberin), which are disposed with intercellular spaces, naming the tissue aerenchymatous 
polyderm. The polyderm of the same organ and species found in well drained soils or emerged in the flooded soils does not have this aerenchymatous aspect [116]. According to [117], these intercellular spaces are filled of gases and longitudinally interconnected emerged parts with immersed parts, providing a low resistance way which facilitates internal diffusion of these gases at long distances throughout the organs of the plant. Although the epidermic cell walls and cuticle of primary roots generally are thin $[63,118]$, any species show thickness of external periclinal and anticlinal walls of epidermic cells in plants submitted to flooding in palm swamps [116]. This thickness could provide protection against adverse conditions near to root surface in the flooded soils [119].

Gelatinous fibers are different of other sclerenchyma fibers because they have a cellulosic thickening in the inner cell walls (figure 9) which, due to artifact of manufacturing of the blade, disconnects from lignified cell walls and stands out [120]. The most accurate way to observe the gelatinous fibers is the color technique using dyes that differs lignin of cellulose. For example, acid floroglucine will stain only the external layer of wall where there is lignin and safranine-fast green, a double staining, that will stain red the lignified wall and green the gelatinous layer, indicating presence of cellulose [121]. This layer is also called mucilaginous layer or " $G$ " layer and generally occurs in tension wood and underground organs [23, 122-123]. Gelatinous fibers are very common in the Cerrado plants and they usually appear associated with the secondary xylem of stem, mainly in the initial layers of the growth ring $[120,124]$ but also may appear on other organs such as petiole and raquis of leaves [121]. Generally, the mucilaginous aspect of " $G$ " layer is linked to the ability of aggregate water because the structure is highly hygroscopic [23].

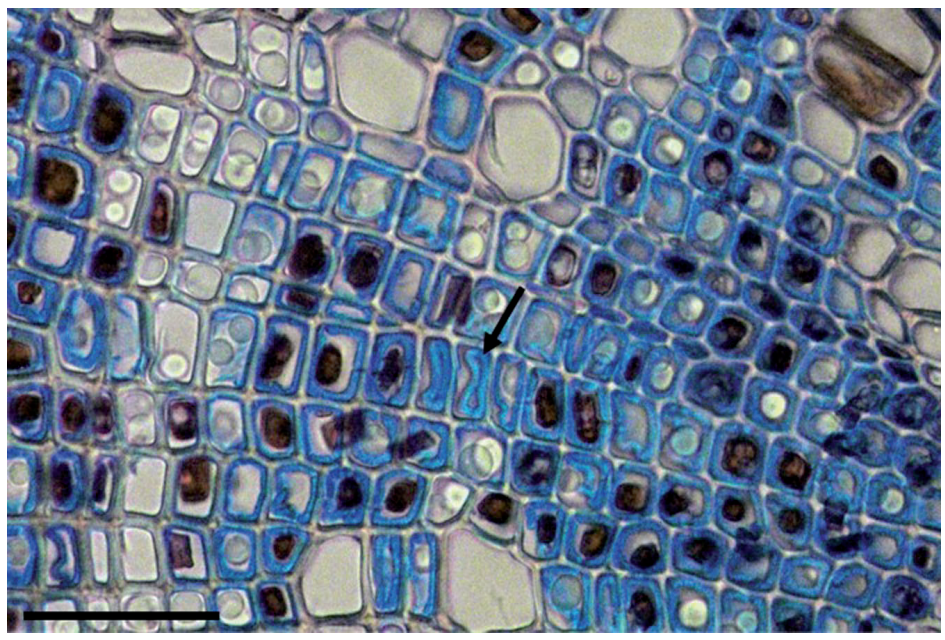

Figure 9. Gelatinous fibers in the secondary xylem of Macairea radula (Bonpl.) DC. (Melastomataceae) stem. Arrow show the "G" layer with cellulosic thickness. Scale bar: $50 \mu \mathrm{m}$. 
In Amaranthaceae species it is common to find a secondary thickening formed by a series of vascular cambia arising successively farther outward from the center of the stem, each producing xylem toward the inside and phloem toward the outside - an anomalous secondary thickening [125-126]. Amaranthus spp. can have two or more rings of primary vascular bundles and a complex organization of leaf traces associated with leaf gaps [127]. Some members of the family have vascular bundles included in the medullary tissue of the shoot, with unknown function, which can contribute to leaf vascularization, as in Melastomataceae and Piperaceae species [128]. The anomalous secondary thickening was found in all investigated members of Amaranthaceae family, which is considered an important group to understand the origin of successive cambia and its products and the variation in the wood anatomy and stem in dicots [126, 129].

Preliminary study of Gomphrena arborescens [56] did not show successive vascular cambia in the secondary thickening of the shoot, but the bidirectional activity of a singular vascular cambia adding more cells in the secondary xylem than in the secondary phloem. There were found nucleated fibers and perimedullary amphicribral vascular bundles near the node regions (figure 10) [56], which were connected to the vascularization of a deriving leaf. Further studies are necessary to determine the function of these elements and the reason to this kind of secondary thickening, although it seems to indicate that this species is in transition from herbal to subshrub habit.

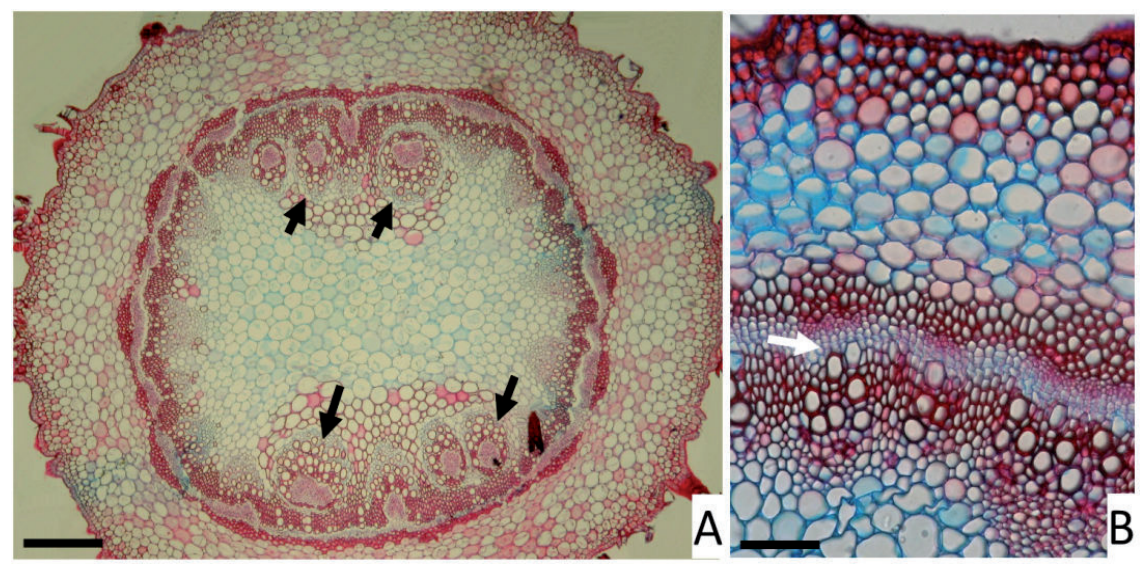

Figure 10. Transverse sections of Gomphrena arborescens L.f. stem. A: Perimedullary amphicribral vascular bundles (black arrow) near the node regions, which were connected to the vascularization of a deriving leaf. B: Bidirectional activity of a singular vascular cambia (white arrow). Scale bars: A: $500 \mu \mathrm{m}$. B: $100 \mu \mathrm{m}$.

Although the Raunkiaer system [130] is widely used to classify the life form of plants based on the level of protection of budding structures, new ecological classifications were proposed in Brazil due to the diversity of the subterranean systems found in our flora [131]. The first researcher to use the term "xylopodium" [132], around the year of 1900, described a lignified 
structure responsible for the regeneration of the aerial parts of a plant, during his studies of the ecology on open fields of Rio Grande do Sul State, in Brazil. Around the year of 1908, [11] another researcher noticed the same structure in Lagoa Santa plants (in Minas Gerais State), but did not attempt to define it. Since then, all the studies trying to understand this organ were concentrated in Cerrado plants [131].

Studying plants with xylopodium in São Paulo State, [133] author concluded that the superficial portion of the subterranean system, which originates the first aerial sprouts after burning, is a small subterranean stem - and sometimes is difficult to understand where the stem finishes and where the root starts. Naturally, the subsequent studies were focused in understanding the ontogenesis and the environment were these plants grow. Another study [134] determined that the xylopodium can be formed by the tuberous growth of the primary root near the soil or by the tuberous growth of the hypocotyl; the first one is due to a disturbed environment which prevents the plant to grow naturally (like in Mimosa multipinna Benth, Stryphnodendron adstringens (Mart.) Coville, Palicourea rigida H.B.K and Kielmeyera coriacea (Mart.) var. glabripes $\mathrm{N}$. Saddi) and the second one is genetics and independent of the environmental conditions (like in Clitoria guianensis Benth. and Calliandra dysantha Benth.). Through the study of the xylopodium of Brasilia sickii (Asteraceae) [23, 135], it was understood that this organ could be considered a morphological unit, but not an anatomical one; it was stated the need of ontogenetic studies to really understand the origin of any plant xylopodium, since it can be originated from the root in a young xylopodium and from the stem in an older one, always with the predominance of xylem tissue, including gelatinous fibers with the ability of storing water. In [62] authors theorized that the cutting-off of the shoots, at the end of every dry season, would favour the development of xylopodium as an adaption to the conditions prevailing in the grassland or "campos" - where these plants are well established. This cutting-off of the shoots could, also, be provided by fire and the hard lignified xylopodium would survive as underground persistent organs of plants that dwell in savannah-like regions with a dry season lasting from 4-6 months [134]. In [136], Mandevilla illustris (Vell.) R.E. Woodson and M. velutina K. Schum. (Apocynaceae) from Cerrado were studied and authors concluded that a same plant can have an underground organ formed by a xylopodium (the hard superior portion) and by a fleshy tuberous root; the xylopodium is formed by a cambium tissue, in the junction of the hypocotyl and the primary root, without the participation of the shoot and retaining the capacity of re-sprout the shoot.

In [23], soboles are indicated as common feature in Cerrado plants, an underground horizontal stem which grow out as an erect plant [137]. Sobole of Annona pygmaea Warm. can be originated from the hypocotyl, in the begging of the development, or from the top of the root when the primary stem is destroyed; the organ can have aerial portions of leaves and is usually a storage organ with well-developed starchy parenchyma; this kind of plant can perform vegetative reproduction, the same way as the other type of root suckers, the gemmiferous root [62].

In this study [131] are described Bauhinia forficata Link, Centrolobium tomentosum Guill. ex Benth, Inga laurina Willd. and other Cerrado tree species with long roots running in parallel to the surface and showing budding shots. The point of origin to the aerial parts was a typical root without medullary tissue and with primary xylem with centripetal maturation, usually 
storing starch [131]. In these cases and in herbal or subshrub species from Cerrado, the underground organ is called gemmiferous roots, the second of the root sucker types [62].

The underground system is very important in Cerrado plants, being linked not only to the anchorage, support and water absorption, but also to carbohydrates and water storage and to vegetative reproduction $[23,138]$. This Biome is subject to fires since remote ages, which could be caused by electrical discharge or by the primitive men as a strategy to hunt and, most recently, in order to open areas to grow crops [22]; in experimental burned Cerrado areas, the surface temperature is about $74{ }^{\circ} \mathrm{C}$ but, under the soil, heating is drastic not so high, varying from $55{ }^{\circ} \mathrm{C}$ one centimeter below and reaching only few degrees at $5 \mathrm{~cm}$ under the surface. Certain savannah species are ephemeral but most of Brazilian Cerrado's species are perennial [22]. Probably, the temperature difference during the fire can allow underground organs to survive, although the aerial parts are burned out; adding to this the budding characteristic of the xylopodium, soboles and gemmiferous roots, the well-developed underground organs of Cerrado's species can explain the prevailing perennial habit.

The underground organ of Gomphrena macrocephala (Amaranthaceae), a Cerrado species, revealed fructan as the main storage carbohydrate; it was the first reference to this polysaccharide in a plant of the superorder Caryophyllidae [139-140]. Fructans are fructose based polysaccharides, usually found in Asteraceae and Gramineae, two of the most evolved families, which indicates it to be a selective advantage [108]. In G. macrocephala, the capacity to store fructans instead of starch was considered an advantage developed in response to the environmental stress of the dry season and eventual fires [141]. The fluctuation in fructan content of G. macrocephala is connected to photoperiodism: shorter days, typical from the dry winter, induce senescence of the aerial organs and increase in the fructan content whilst long days, typical of the rainy summer, stimulated the development of the aerial organs and resulted in shortage of fructan content [142]. A well-marked seasonality of fructan accumulation was found in tuberous roots of Gomphrena marginata Seub. [143] and authors correlated it with seasonal changes in the availability of water in the soil; the content of fructans decreased during the rainy season and increased during the dry season, keeping almost steady the relative water content of the underground organs. Preliminary data show that tuberous roots of G. arborescens only stores fructan (figure 11), whilst in the shoot there was found starch [56]. As $G$. arborescens roots are used in folk medicine to reduce fever, against asthma and bronchitis or as tonic [144-147], along with other Amaranthaceae species used for the same purposes, the isolation and study of their fructans could help to understand the origin of its folk medicinal properties. In roots of Arctium lappa L., var. herkules there were fructans from inuline series which were proved to be biologically active as cough-suppressing agent in a cat model in vivo; the activity of these fructans in suppressing cough was compared to the parameters stablished for antitussive efficiency of drugs commonly used in clinical practice [148]. So, more than a challenge to understand the morphology and anatomy of the underground system in Amaranthaceae species, it is also necessary a more comprehensive study of the carbohydrates and phenology of another species of this family, even to determine if the presence of fructan is widespread or restricted to some members or genera of the family. 

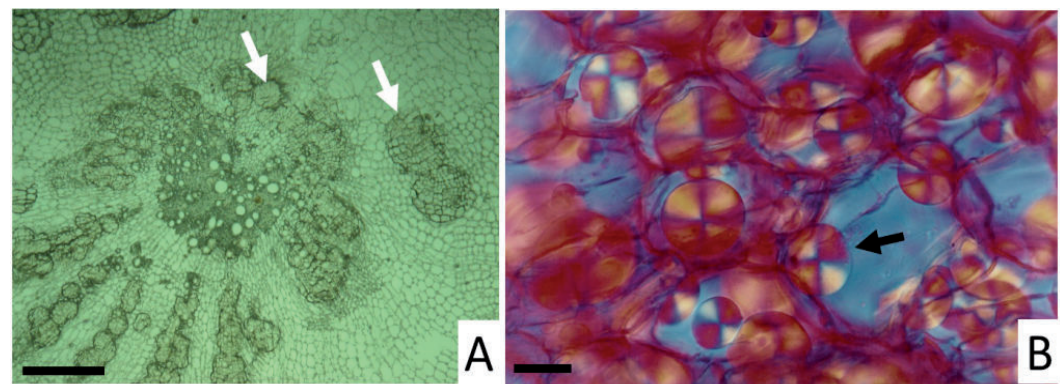

Figure 11. Transverse sections of Gomphrena arborescensL.f. root. A: After treatment in pure ethanol for at least 7 days, clusters of spherical fructan crystals (white arrow) appear in the cortex region. B: Spherical fructan crystals (black arrow) under polarized light, after dying the section with safranine ethanolic solution. Scale bars: A: $500 \mu \mathrm{m}$. B: $100 \mu \mathrm{m}$.

\section{Retrospective and perspectives about Cerrado knowledge and structural studies}

Much of the actual knowledge about the Brazilian savannah or Cerrado Biome and its vegetation is derived from a group of researchers who shared their point of views in a series of Symposia, organized initially by them in order to gather efforts and develop multidisciplinary research in networks, mostly by initiative of teachers of USP - the São Paulo University [10], who also republished in Portuguese some very important works done by the first foreign researchers [10-11, 132]. The first Symposium was realized in 1962, in São Paulo city: the "Simpósio Nacional do Cerrado" was intended to improve the knowledge to grow crops and raise cattle in the region [149]; the second one was realized in Rio de Janeiro, in 1965, where people concluded that most of the knowledge about Cerrado was related to the plant biology and that would be necessary to realize a multidisciplinary approach to create a national policy and also to undertake basic and applied research. The third event was again in São Paulo, in 1971, and gathered so many researchers that it was necessary to realize simultaneous meetings and extend the event in order to allow everybody to present their works [10, 149].

From the year 1975 on, the federal government created a set of programs to speed up the development of federal States in the center of the Cerrado Biome (Goiás, Minas Gerais, Mato Grosso and Federal District) through financial aid for the construction of roads, schools and warehouses, funding agricultural research, providing technical assistance to incorporation of new areas into the production process and encouraging the use of limestone and phosphate to correct the soil pH, among others [150]. More than that, Brazilian Enterprise for Agricultural Research - EMBRAPA - a state-owned company affiliated with the Brazilian Ministry of Agriculture, created its unit Embrapa Cerrados (CPAC) with the aim of developing agricultural systems viable to the Cerrado Biome and to give technical support to farmers. So, from the fourth Symposium on, realized in 1976, these events were done in Brasília, with the incentive of Embrapa Cerrados; collecting important data for agricultural development, all the 
work done in this event was of great value to improve the newly approved policy of the Program for Development of Cerrados [149].

According to [149], all the information gathered wasn't still enough to support the region development, mostly because they were generalized. Among other problems [149], there were: irregular distribution of rain (a challenge to grow crops), the soils low level of fertility, inadequate methods used to cultivate soils leading to soil exhaustion, incidence of illness in monotypic crops and few knowledge about environmental, economic and social peculiarities of the core region of the Cerrado Biome. Embrapa Cerrado leaded the development of networks with institutes, universities, other Embrapa units and state companies to obtain systematic data on every field of interest to understand and complete the knowledge gaps in order fulfill its own mission. The knowledge gained through political, technical and economic focus, transferred as technical support to the farmers, created a scale gain which benefited all the participants; the technology incorporated by the farmers implicated in rapid increase of cultivated area [149], at a speed that is not currently possible to maintain without a huge loss of biodiversity.

In 1979 the Symposium theme was "Cerrado: use and management" and in 1982 it was the begging of the international comprisement of the event, which was themed "Savannah: food and energy" and shared the concerns in the use of this kind of environment around the world [149]. In 1989, the seventh Symposium was done in order to gather data on the increasing efficiency to produce crops and, in 1996, the VIII National Symposium and the I International Symposium were done in a year where the cultivated area in Cerrado Biome was four times more efficient, during the onset of environmental damages such as soil degradation, weed spreading and pests; from then to now, the rational usage of savannah areas is the main concern [149-150].

In 2006 [149], the Cerrado region contributed to 33\% of the Brazilian Gross Domestic Product, employing around $40 \%$ of the labor force. So, in 2008 the theme "Challenges and strategies for the equilibrium between society, agribusiness and natural resources" [149] was chosen to delineate the main discussions of the IX National Symposium of Cerrado and the II International Symposium of Tropical Savannas; in the third chapter [149] there is a review, in English, about the importance of savannah environments to the global climate change, emphasizing the distribution of this kind of environment in the world, not only in tropical regions of Africa, South America, Asia and Pacific, but also in temperate climate regions of North America (prairies) and derived savannahs in Europe.

According to [151] tropical savannahs are characterized by physiognomies with trees and shrubs and abundance of herbs from Poaceae and Cyperaceae families over dystrophic and sandy soils under a climate with seasonal rainfall. The predominance of bushes and trees over grasses depends on the soil fertility and fire as a natural or anthropomorphic phenomenon, among other environmental characteristics [151]. However, savannah flora presents differences: whilst Australian and African savannahs have more deciduous species among bushes and trees, evergreen species are the main representatives of these groups in Brazilian savannah [151-152]. African species can close leaf stomata very rapidly, but this is not the rule for Brazilian species, although there are some exceptions; this characteristic and the deciduous- 
ness can be linked to the shallow root system of African species [151]. Similar to the subterranean organs of Brazilian species earlier cited in this chapter, Australian savannah species develop lignotubers [153-154] with regenerative and storage functions which allows the resprout after fire. Tropical savannahs are considered more suitable to intensive grain cropping and livestock production, but it is necessary to ponder the need of food production and give value to the ecosystem services of this environment, as the maintenance of fresh water resources and moderation of the Carbon cycle, in order to create another income source for farmers [150] over preserved land.

Although there is a lot of data obtained already for Cerrado species, due to the research network which leaded to the creation of Embrapa Cerrados, and later by the increase of the number and quality of the networks created by Embrapa itself and by other Federal Government Agencies policies (as the Milenium Institutes Program, the National Institutes for Science and Technology-INCT Program and the Long-Term Ecological Research Program - PELD, from $\mathrm{CNPq}$ ), some basic structural studies are still needed to improve the knowledge about the huge diversity of Cerrado's species (plants, fungi and fauna), preferably multidisciplinary ones, ranging from ecology, morphology and taxonomy to the anatomy and cell biology of species. The structural knowledge is the basis to further development of applied studies (preservation, investigation of pharmacological properties and others). For example, histochemical investigation in plants can help taxonomy [155-156] and the establishment of patterns for quality control of drugs or micro-scale identification of the potential origin of pharmacological properties in Folk medicinal plants, but it is necessary special preparation and fresh material at your disposal [26]. Mostly because of the time consuming and the high cost of pharmacological and pharmaceutical studies, in Brazil there are a great amount of plants used by the population as medicinal [144-147] without almost any scientific study to confirm it.

Since the high humidity and intense heat of the Cerrado's rainy season favours the development of fungal hyphae on leaf surfaces, including on the Amaranthaceae species Gomphrena arborescens, G. pohlii and G. virgata [46, 58], the study of the plant-microorganism interaction also can lead to a wide range of applications; for example, health risks to human or stock farming animals' can be avoided simply by preventing the consumption of contaminated food or the medicinal plant. Plants offer a wide range of habitats for microorganisms, including its aerial parts, rhizosphere and internal transport system [157]. This kind of interaction contributes to the environmental equilibrium and can play essential roles in agricultural and food safety [157-158]. The plant metabolites against endophytic invaders could be isolated and used for the genetic improvement of crop biochemical defenses; selected microorganism metabolites can be isolated to act as a biological control of crop diseases and herbivores [157].

These and other fields of study demands the basic studies of taxonomy, morphology and anatomy in order to be properly interpreted and, later, lead to application not only on the increase of crop production, but also in the conservation of the few areas of the Cerrado Biome which are still preserved, mostly due to some Conservation Units created to integrate the Conservation Unit System of Brazil. Goiás State is in the center region of the Cerrado Biome and only $15 \%$ of the natural savannah was protected in 2002 [159]; originally, savannah vegetation represented $50 \%$ of the State territory, and the author claims that the remaining 
species biodiversity will only be found in Conservation Units about a hundred years from now.

According to [160] the apparent dichotomy between food production and preservation of the natural vegetation is not impossible, because Brazil has already cleared enough area to support all food, fiber and bioenergy production that is necessary to meet not only the own country needs but also the global market. So, maybe it is time to set a new policy not only for agricultural and livestock development, but also to improve infrastructure and the efficiency of these activities and for encouraging and expanding the Conservation Unit System in order to better preserve the huge biodiversity of flora and fauna and its direct and indirect benefices to Brazilian people, now and through the significant amount of research that is still to be done.

\title{
Acknowledgements
}

\author{
CAPES, CNPq, FAPDF, FINEP
}

\section{Author details}

Suzane Margaret Fank-de-Carvalho ${ }^{1^{*}}$, Nádia Sílvia Somavilla ${ }^{2}$, Maria Salete Marchioretto ${ }^{3}$ and Sônia Nair Báo ${ }^{4}$

*Address all correspondence to: suzifankcarvalho@gmail.com

1 Bioscience Coordination, Conselho Nacional de Desenvolvimento Científico e Tecnológico - CNPq, Brasilia, Brazil

2 Botany Department, Institute of Biological Sciences, Universidade Federal de Juiz de Fora - UFJF, Juiz de Fora,, Brazil

3 PACA Herbarium, Instituto Anchietano de Pesquisas, São Leopoldo, Brazil

4 Cell Biology Department, Institute of Biological Sciences, Universidade de Brasília - UnB, Brasília, Brazil

\section{References}

[1] Forzza RC., Leitman PM., Costa AF., Carvalho Jr. AA., : Peixoto AL., Walter BMT., Bicudo C., Zappi D., Costa DP., Lleras E., Martinelli G., Lima HC., Prado J., Stehmann JR., Baumgratz JFA., Pirani JR., Sylvestre L., Maia LC., Lohmann LG., Queiroz LP., Silveira M., Coelho MN, Mamede MC, Bastos MNC, Morim MP, Barbosa MR, 
Menezes M, Hopkins M, Secco R., Cavalcanti TB., Souza VC. Catálogo de Plantas e Fungos do Brasil-Vol. 1. Rio de Janeiro: Andrea Jakobsson Estúdio/Instituto de Pesquisa Jardim Botânico do Rio de Janeiro; 2010.

[2] Myers N., Mittermeier RA., Mittermeier CG., Fonseca GAB., Kent J. Biodiversity hotspots for conservation priorities. Nature 2000;403 853-858.

[3] Klink CA., Machado RB. A conservação do Cerrado brasileiro. Megadiversidade 2005;1(1) 147-155.

[4] Dias BFS. Alternativas de desenvolvimento dos cerrados: manejo e conservação dos recursos naturais renováveis. Brasília: FUNATURA/IBAMA; 1992.

[5] Miranda H., Miranda AC.. Queimadas e estoques de carbono no Cerrado. In: Moreira AG., Schwartzman S. (eds). As Mudanças Climáticas e os Ecossistemas Brasileiros, Brasília: Ed. Foco; 2000. p75-81.

[6] Simon MF., Proença C. Phytogeographic patterns of Mimosa (Mimosoideae, Leguminosae) in the Cerrado biome of Brazil: an indicator genus of high-altitude centers of endemism? Biological Conservation 2000;96 279-296.

[7] Eiten G. Vegetação natural do Distrito Federal. Brasília: SEBRAE/UNB; 2001.

[8] Miranda HS., Sato MN., Nascimento Neto W., Aires FS. Fires in the cerrado, the Brazilian savanna. In: Cockrane MA. (ed.) Tropical Fire Ecology-climate change, land use, and ecosystem dynamics. Berlin: Springer; 2009. p427-450.

[9] Eiten G. Cerrado vegetation of Brazil. The Botanical Review 1972;38(2) 201-341.

[10] Ferri MG. A vegetação de Cerrados Brasileiros. In: Warming E., Ferri MG. Lagoa Santa e a vegetação dos Cerrados Brasileiros. Belo Horizonte: Itatiaia; São Paulo: EDUSP; 1973. p285-386.

[11] Warming E. Lagoa Santa. In: Warming E., Ferri MG. Lagoa Santa e a vegetação dos Cerrados Brasileiros. Belo Horizonte: Itatiaia; São Paulo: EDUSP; 1973. p1-284.

[12] Rawitscher F., Ferri MG., Rachid M. Profundidade dos solos e vegetação em campos cerrados do Brasil Meridional. Anais da Academia Brasileira de Ciência 1943;15(4) 267-294.

[13] Rachid-Edwards M. Alguns dispositivos para proteção de plantas contra a seca e o fogo. Boletim da Faculdade de Filosofia Ciências e Letras da Universidade de São Paulo-Botânica 1956;58(5) 39-68.

[14] Arens K. O cerrado como vegetação oligotrófica. Boletim da Faculdade de Filosofia Ciências e Letras da Universidade de São Paulo-Botânica 1958;15 59-77.

[15] Goodland R. Oligotrofismo e alumínio no Cerrado. In: Ferri MG. (coord). III Simpósio sobre o Cerrado. São Paulo: Ed. USP; São Paulo: Ed. Edgard Blücher; 1971. p44-60. 
[16] Queiroz-Neto JP. Solos da região dos cerrados e suas interpretações (revisão de literatura). Revista Brasileira de Ciência do Solo 1982;6 1-12.

[17] Reatto A., Correia JR., Spera ST. Solos do bioma Cerrado: aspectos pedológicos. In: Sano.M., Almeida SP.(eds.) Cerrado: Ambiente e Flora. Planaltina: Embrapa; 1998. p47-86.

[18] Haridasan M. Aluminum accumulation by some cerrado native species of central Brazil. Plant and Soil 1982;65 265-273.

[19] Chenery EH. Aluminum in the plant world. Part I. General survey in the dicotyledons. Kew Bulletin 1948;3 173-183.

[20] Haridasan M. Alumínio é um elemento tóxico para as plantas nativas do cerrado? In: Prado CHBA, Casali CA. (eds.) Fisiologia Vegetal: práticas em relações hídricas, fotossíntese e nutrição mineral. Barueri: Manole; 2006.

[21] Ratter JA., Richards PW., Argent G., Gifford DR. Observations on the forests of some mesotrophic soils in central Brazil. Revista Brasileira de Botânica 1978;1 47-58.

[22] Coutinho LM. As queimadas e seu papel ecológico. Brasil Florestal 1980;10(44) 7-23.

[23] Paviani TI. Anatomia vegetal e cerrado. Ciência e Cultura 1978;30(9) 1076-1082.

[24] Paviani TI. Situação da anatomia ecológica no Brasil. Ciência e Cultura 1984;36(6) 927-932.

[25] Paiva PHV. A Reserva da Biosfera do Cerrado: fase II. In: Cavalcanti TB., Walter BMT. (eds.) Tópicos atuais em botânica-palestras convidadas do $51^{\circ}$ Congresso Nacional de Botânica. Brasília: Sociedade Brasileira de Botânica/Embrapa-Cenargen; 2000. p332-334.

[26] Fank-de-Carvalho SM. Graciano-Ribeiro D. Arquitetura, anatomia e histoquímica das folhas de Gomphrena arborescens L. f. (Amaranthaceae). Acta Botanica Brasilica 2005;19(2) 377-390.

[27] Bridson D., Forman L. The herbarium handbook. Richmond: Royal Botanic Gardens Kew; 1992.

[28] Joly AB. Botânica: Chaves de identificação das plantas vasculares que ocorrem no Brasil, baseadas em chaves de Franz Thomer. 3. ed. São Paulo: Cia Ed. Nacional; 1977.

[29] Barroso GM., Guimarães EF., Ichaso CLF., Costa CG., Peixoto AL. Sistemática de Angiospermas do Brasil. v1. Rio de Janeiro: Livros Técnicos e Científicos Editora SA; 1978.

[30] Barroso GM., Peixoto AL., Ichaso CLF., Costa CG., Guimarães EF., Lima HC. Sistemática de Angiospermas do Brasil. Vol. 2. Viçosa: Imprensa Universitária, Universidade Federal de Viçosa; 1984 
[31] Barroso GM., Peixoto AL., Ichaso CLF., Costa CG., Guimarães EF., Lima HC. Sistemática de Angiospermas do Brasil. Vol. 3. Viçosa: Imprensa Universitária, Universidade Federal de Viçosa; 1984

[32] Agarez FV., Pereira C., Rizzini CM. Botânica Angiospermae: Taxonomia, morfologia, reprodução: chave para determinação das famílias. 2ed. Rio de Janeiro: Âmbito Cultural; 1984 .

[33] Siqueira JC. Amaranthaceae. In: Wanderley MGL., Shepherd G., Giulietti AM. (eds.) Flora Fanerogâmica do Estado de São Paulo. São Paulo: FAPESP-HUCITEC; 2002. p11-30.

[34] Marchioretto MS., Windisch PG., Siqueira JC. Os gêneros Froelichia Moench e Froelichiella R.E. Fries (Amaranthaceae) no Brasil. Pesquisas-Botânica 2002;52 7-46.

[35] Marchioretto MS. Os gêneros Hebanthe Mart. e Pfaffia Mart. (Amaranthaceae) no Brasil.PhD thesis. Universidade Federal do Rio Grande do Sul; 2008.

[36] Marchioretto MS., Miotto STS., Siqueira JC. O gênero Hebanthe (Amaranthaceae) no Brasil. Rodriguésia 2009;60(4) 783-798.

[37] Marchioretto MS., Miotto STS., Siqueira JC. O gênero Pfaffia Mart. (Amaranthaceae) no Brasil. Hoehnea 2010;37(3): 461-511.

[38] Jardim Botânico do Rio de Janeiro. Amaranthaceae. In: Marchioretto MS., Senna L., Siqueira JC. Lista de Espécies da Flora do Brasil. http://floradobrasil.jbrj.gov.br/jabot/ floradobrasil/FB42 (accessed 20 May 2014)

[39] Kraus JE., Arduin M. Manual básico de métodos em morfologia vegetal. Rio de Janeiro: EDUR; 1997.

[40] Souza W. (ed.) Técnicas básicas de microscopia eletrônica aplicadas às ciências biológicas. 3ed. Rio de Janeiro: Sociedade Brasileira de Microscopia; 2010.

[41] Paiva EAS. Effect of sample preparations for SEM studies of epicuticular wax in Tradescantia pallida (Commelinaceae) leaves. Brazilian Journal of Morphological Sciences supplement 2005; 258.

[42] Siqueira JC. O gênero Gomphrena L. (Amaranthaceae) no Brasil. Pesquisas-Botânica 1992; 43: 5-197.

[43] Siqueira JC. Fitogeografia das Amaranthaceae Brasileiras. Pesquisas-Botânica 1995; 45: 5-21.

[44] Siqueira JC. Amaranthaceae: padrões de distribuição geográfica e aspectos comparativos dos gêneros Africanos e Sulamericanos. Pesquisas-Botânica 2004; 55: 177-185,

[45] Moraes Neto SP. Acidez, alcalinidade e efeitos da calagem no solo. Planaltina, DF: Embrapa Cerrados. 2009. http://www.cpac.embrapa.br/noticias/artigosmidia/publicados/112/ (accessed 21 July 2014). 
[46] Salatino A., Montenegro G.; Salatino MLF. Microscopia eletrônica de varredura de superfícies foliares de espécies lenhosas do cerrado. Revista. Brasileira de Botânica 1986; 9: 117-124.

[47] Fank-de-Carvalho SM. Contribuição ao conhecimento da anatomia, micromorfologia e ultraestrutura foliar de Amaranthaceae do Cerrado. Thesis. Instituto de Biologia, Doutorado em Biologia Celular e Estrutural, Universidade Estadual de Campinas, Campinas, SP, Brazil; 2011.

[48] Fank-de-Carvalho SM., Báo SN., Marchioretto MS. Amaranthaceae as a bioindicator of neotropical savannah diversity. In: Lameed GA. (ed.). Biodiversity enrichment in a diverse world. Rijeka: InTech; 2012. p235-262.

[49] Monteiro-Scanavacca WR. Vascularização floral em Amaranthaceae. Ciência e Cultura $1971 ; 23(3)$ 339-349.

[50] Laboriau MLS. Pollen grain of plants of the "Cerrado"-I. Anais da Academia Brasileira de Ciências 1961; 33(1) 119-130.

[51] Judd WS., Campbell CS., Kellogg EA., Stevens PF., Donoghue MJ. Plant systematics. A Phylogenetic approach. 2ed. Sunderland, Sinauer Associates; 2002.

[52] Siqueira JC. Frutos e unidades de dispersão em Amaranthaceae. Eugeniana 1984; 7 3-11.

[53] Pijl, L. van der. (1982). Principles of dispersal in higher plants. Berlim Springer-Verlang, Heidelberg; 1982.

[54] Coutinho ML. Aspectos ecológicos no Cerrado II. As queimadas e a dispersão de sementes em algumas espécies anemocórias do estrato herbáceo-subarbustivo. Boletim Botânico da Universidade de São Paulo 1977; 5 57-64.

[55] Marchioretto MS., Windisch PG., Siqueira JC. Problemas de conservação das espécies dos gêneros Froelichia Moench e Froelichiella R. E. Fries (Amaranthaceae) no Brasil. Acta Botânica Brasílica 2005; 19(2) 215-219.

[56] Fank-de-Carvalho SM. (2004). Contribuição ao conhecimento botânico de Gomphrena arborescens L.f. (Amaranthaceae)-estudos anatômicos e bioquímicos. (Dissertation). Instituto de Ciências Biológicas, Mestrado em Botânica, Universidade de Brasília, Brasília, DF, Brazil; 2005.

[57] Fank-de-Carvalho SM., Marchioretto MS., Báo SN. Anatomia foliar, morfologia e aspectos ecológicos das espécies da família Amaranthaceae da Reserva Particular do Patrimônio Natural Cara Preta, em Alto Paraíso, Goiás, Brasil. Biota Neotropica 2010; 10 77-86.

[58] Fank-de-Carvalho SM., Gomes MRA., Silva PIT., Báo SN. Leaf surfaces of Gomphrena spp. (Amaranthaceae) from Cerrado biome. Biocell 2010; 34(1) 23-35. 
[59] Miranda HS., Sato MN. Efeitos do fogo na vegetação lenhosa do Cerrado. In: Scariot A., Sousa-Silva JC., Felfilli JM. (eds.). Cerrado: ecologia, biodiversidade e conservação. Brasília: Ministério do Meio Ambiente; 2005. p 95-105.

[60] Cirne P. Efeitos do fogo na regeneração da lenhosa Kielmeyera coriacea em áreas de cerrado sensu stricto: mecanismos de sobrevivência e época de queima. Thesis. Universidade de Brasília, Brasília, Brasil; 2000.

[61] Somavilla NS., Graciano-Ribeiro G. Análise comparativa da anatomia foliar de Melastomataceae em ambiente de vereda e cerrado sensu stricto. Acta Botanica Brasílica 2011; 25 764-775.

[62] Rizzini CT., Heringer EP. Underground organs of plants from some southern Brazilian savannas, with special reference to the xylopodium. Phyton 1961; 17 105-124.

[63] Fahn A. Structural and functional properties of trichomes of xeromorphic leaves. Annals of Botany 1986; 57 631-637.

[64] Dickinson WG. 2000. Integrative plant anatomy. San Diego: Academic Press; 2000.

[65] Poorter L., Bongers F. Leaf traits are good predictors of plant performance across 53 rain forest species. Ecology 2006; 87 1733-1743.

[66] Kitajima K., Mulkey SS., Wright SJ. Decline of photosynthetic capacity with leaf age in relation to leaf longevities for five tropical canopy tree species. American Journal of Botany 1997; 84 702-708.

[67] Reich PB., Wright IJ., Cavender-Bares J., Craine JM., Oleksyu J., Westtoby M., Walter MB. The evolution of plant functional variations: traits, spectra, and strategies. International Journal of Plant Sciences 2003; 164 (S3) S143-S164.

[68] Wright IJ., Reich PB., Westoby M., Ackerly DD., Baruch Z., Bongers F., CavenderBares J., Chapin FS., Cornelissen JHC., Diemer M., Flexas J., Garnier E., Groom PK., Gulias J., Hikosaka K., Lamont BB., Lee T., Lee W., Lusk C., Midgley JJ., Navas ML.,Niinemets U., Oleksyn J., Osada N., Poorter H., Poot P., Prior L., Pyankov VI., Roumet C., Thomas SC., Tjoelker MG., Veneklaas EJ., Villar R. The worldwide leaf economics spectrum. Nature 2004; 428 821-827.

[69] Rossatto DR., Hoffmam WA., Franco AC. Differences in growth patterns between coocurring forest and savanna trees affect the forest-savanna bondary. Functional Ecology 2009; 23 689-698.

[70] Rossatto DR., Kolb RM. An evergreen Neotropical savanna tree (Gochnatia polymorpha, Asteraceae) produces different dry-and wet-season leaf types. Australian Journal of Botany 2009; 57 439-443.

[71] Reis C., Bieras AC., Sajo MG. Anatomia foliar de Melastomataceae do Cerrado do Estado de São Paulo. Revista Brasileira de Botânica 2005; 28 451-466. 
[72] Bieras AC., Sajo MG. Leaf structure of the cerrado (Brazilian savanna) woody plants. Trees 2009; 23 451-471.

[73] Somavilla NS., Kolb RM., Rossatto DR. Leaf anatomical traits corroborate the leaf economic spectrum: a case study with deciduous forest tree species. Brazilian Journal of Botany 2014; 37 69-82.

[74] Mott KA., Gibson AC., O'Leary JW. The adaptive significance of amphistomatic leaves. Plant, Cell and Environment 1982; 5: 455-460.

[75] Mott KA., Michaelson O. Amphistomy as an adaptation to high light intensity in Ambrosia cordifolia (Compositae). American Journal of Botany 1991; 78(1) 76-79.

[76] Parkhurst DF. The adaptative significance of stomatal occurrence on one or both surfaces of leaves. Journal of Ecology 1978; 66(2) 367-383.

[77] Gomes SM., Somavilla NSD., Gomes-Bezerra KM., Miranda SC., De-Carvalho PS., Graciano-Ribeiro D. 2009. Anatomia foliar de espécies de Myrtaceae: contribuições à taxonomia e filogenia. Acta Botanica Brasilica 2009; 23 (1) 223-238.

[78] Haberland, G. Physiological plant anatomy. London, MacMilan Company Ltd.; 1928.

[79] Sousa HC. Estudo comparativo de adaptações anatômicas em órgãos vegetativos de espécies de Lavoisiera DC. (Melastomataceae) da Serra do Cipó, MG. Thesis. Universidade de São Paulo, São Paulo; 1997.

[80] Milanez CRD., Machado SR. Leaf emergences in Microlepsis oleaefolia (DC.) Triana (Melastomataceae) and their probable function: an anatomical and ultrastructural study. Micron 2007; 39 (7) 884-890.

[81] Landry LG., Chapple CCS., Last RL. Arabidopsis mutants lacking phenolic sunscreens exhibit enhanced Ultraviolet-B injury and oxidative damage. Plant Physiology 1995;109 1159-1166.

[82] Booij-James IS., Dube SK., Jansen MAK., Edelman M., Mattoo AK. Ultraviolet-B radiation impacts light-mediated turnover of the photosystem II reaction center heterodimer in Arabidopsis mutants altered in phenolic metabolism. Plant Physiology 2000; 124 1275-1284.

[83] Bieza K., Lois R. An Arabidopsis mutant tolerant to lethal ultraviolet-B levels shows constitutively elevated accumulation of flavonoids and other phenolics. Plant Physiology 2001; 126 1105-1115.

[84] Figueroa FL., Korbee N., Carrillo P., Medina-Sánchez JM., Mata M., Bonomi J., Sánchez-Castillo PM. The effects of UV radiation on photosynthesis estimated as chlorophyll fluorescence in Zygnemopsis decussata (Chlorophyta) growing in a high mountain lake (Sierra Nevada, Southern Spain). Journal of Limnology 2009; 68 206-216. 
[85] Izaguirre MM., Mazza CA., Svatos A., Baldwin IT., Ballar CL. Solar ultraviolet-B radiation and insect herbivory trigger partially overlapping phenolic responses in Nicotiana attenuata and Nicotiana longiflora. Annals of Botany 2007; 99 103-109.

[86] Press MC. The functional significance of leaf structure: a search for generalizationsresearch reviews. New Phytologist 1999; 143 213-219.

[87] Edwards GE., Franceschi VR., Voznesenskaya EV. Single-cell C4 photosynthesis versus dual-cell (Kranz) paradigm. Annual Review of. Plant Biology. 2004; 55 173-96.

[88] Sage RF. The Evolution of C4 photosynthesis. New Phytologist. 2004; 161 (2) 341-370.

[89] Kadereit G., Borsh T., Weising K., Freitag H. Phylogeny of Amaranthaceae and Chenopodiaceae and the evolution of $\mathrm{C} 4$ photosynthesis. International Journal of Plant Sciences 2003; 164 (6) 959-986.

[90] Laetsch WM. The C4 syndrome: a structural analysis. Annual Review of Plant Physiology 1974; 25 27-52.

[91] Sage RF., Monson RK. (eds). C4 Plant Biology. United States of America: Academic Press; 1999.

[92] Gutschick VP. Biotic and abiotic consequences of differences in leaf structure-research reviews. New Phytologist 1999; 143 3-18.

[93] Carolin RC., Jacobs, SWL., Vesk M. Kranz cells and mesophyll in the Chenopodiales. Australian Journal of Botany 1978; 26 683-698.

[94] Black CC. Jr., Mollenhauer HH. Structure and distribution of chloroplasts and other organelles in leaves with various rates of photosynthesis. Plant Physiologist 1971; 47 15-23.

[95] Edwards GE., Franceschi VR., Ku MSB., Voznesenskaya HV., Pyankov VI., Andreo CS. Compartmentation of photosynthesis in cells and tissues of C4 plants. Journal of Experimental Botany 2001; 52(536) 577-590.

[96] Sage RF. C4 photosynthesis in terrestrial plants does not require Kranz anatomy. Trends in Plant Science 2002; 7 283-285.

[97] Voznesenskaya EV., Edwards GE., Kiirats O., Artyusheva EG., Franceschi VR. Development of biochemical specialization and organelle partitioning in the single-cell C4 system in leaves of Borszczowia aralocaspica (Chenopodiaceae). Annals of Botany 2003; 90(12) 1669-1680.

[98] Handro W. Contribuição ao estudo da venação e anatomia foliar das amarantáceas dos cerrados. Anais da Academia Brasileira de Ciências 1964; 36(4) 479-499.

[99] Handro W. Contribuição ao estudo da venação e anatomia foliar das amarantáceas dos cerrados. II-Gênero Pfaffia. Anais da Academia Brasileira de Ciências 1967; 39(3/4) 495-506. 
[100] Gavilanes ML. Estudo anatômico do eixo vegetativo de plantas daninhas que ocorrem em Minas Gerais. 1. Anatomia foliar de Gomphrena celosioides Mart. (Amaranthaceae). Ciência e Agrotecnologia 1999; 23(4) 881-898.

[101] Duarte MR., Debur MC. Characters of the leaf and stem morpho-anatomy of Alternanthera brasiliana (L.) O. Kuntze, Amaranthaceae. Brazilian Journal of Pharmaceutical Sciences 2004; 40(1) 85-92.

[102] Estelita-Teixeira ME., Handro W. Leaf ultrastructure in species of Gomphrena and Pfaffia (Amaranthaceae). Canadian Journal of Botany 1984;.62(4) 812-817.

[103] Antonucci NP. Estudos anatômicos, ultra-estruturais e bioquímicos da síndrome Kranz em folhas de duas espécies de Gomphrena L. (Amaranthaceae). Dissertation. Universidade Estadual de São Paulo; 2010.

[104] Ueno O. Immunogold localization of photosynthetic enzymes in leaves of various C4 plants, with particular reference to pyruvate orthophsphate dikinase. Journal of Experimental Botany 1998; 49(327) 1637-1646

[105] Muhaidat R., Sage RF., Dengler NG. Diversity of Kranz anatomy and biochemistry in C4 eudicots. American Journal of Botany 2007; 94(3) 362-381.

[106] Rajendrudu G., Prasad JSR., Rama Das VS. C3-C4 species in Alternanthera (Amaranthaceae). Plant Physiology 1986; 80 409-414.

[107] Buchanan BB., Gruissem W., Jones RL. Biochemistry \& Molecular Biology of Plants. U.S.A: American Society of Plant Physiologist; 2000.

[108] Lewis DH. Occurrence and distribution of storage carbohydrates in vascular plants. Pp. 1-52. In.: Lewis DH. (ed) Storage carbohydrates in vascular plants. Cambridge University Press: Society for Exp. Biology, Seminar; 1984. p1-52. Series 19.

[109] Borsch T. Clemants S., Mosyakin S. Symposium: Biology of the Amaranthaceae-Chenopodiaceae alliance. Journal of the Torrey Botanical Society 2001; 128(3) 234-235.

[110] Volk GM., Goss LJ., Franceschi VR. Calcium Channels are Involved in Calcium Oxalate Crystal Formation in Specialized Cells of Pistia stratiotes L. Annals of Botany 2004; 93 741-753.

[111] Bréhelin C., Kessler F. The plastoglubule: a bag full of lipid biochemistry tricks. Photochemistry and Photobiology 2008; 84(6) 1388-1394.

[112] Grennan AK. Plastoglobule proteome. Plant Physiology 2008; 147 443-445.

[113] Upchurch R.G. Fatty acid insaturation, mobilization and regulation in the response of plants to stress. Biotechnology Letters 2008; 30 967-977.

[114] Kutík J. The development of chloroplast structure during leaf ontogeny. Photosynthetica 1998; 35 (4) 481-505.

[115] Mendonça RC., Felfili JM., Walter BMT., Silva-Junior MC., Rezende AV., Filgueiras TS., Nogueira PE., Fagg CW. Flora vascular do Bioma Cerrado: checklist com 12.356 
espécies. In: Sano SM., Almeida SP., Ribeiro JF. (Eds.) Cerrado: ecologia e flora. Vol.. 2. Brasília: Embrapa Cerrados; 2008. p 421-1181.

[116] Somavilla NS., Graciano-Ribeiro G. Ontogeny and characterization of aerenchymatous tissues of Melastomataceae in the flooded and well-drained soils of a Neotropical savanna. Flora 2012; 207 2012-222.

[117] Armstrong W., Brele R., Jackson MB. Mechanisms of flood tolerance in plants. Acta Botanica Neerlandica 1994; 43 307-358.

[118] Esau K. Anatomia das plantas com sementes. São Paulo: Edgard Blücher; 1976.

[119] Ponnamperuma, F.N. Effects of flooding soils. In: Kozlowski TT. (ed.). Flooding and Plant Growth. Califórnia: Academic Press; 1984. p9-45.

[120] Marcati CR., Angyalossy-Alfonso V., Benetati L. Anatomia comparada do lenho de Copaifera langsdorfii Desf. (Leguminosae-Caesalpinioideae) de floresta e cerradão. Revista Brasileira de Botânica 2001; 24(3) 311-320.

[121] Mendes ICA., Paviani TI. Morfo-anatomia comparada das folhas do par vicariante Plathymenia foliolosa Benth. e Plathymenia reticulata Benth. (Leguminosae-Mimosoideae). Revista Brasileira de Botânica 1997; 20 185-195.

[122] Evert RF. Esau's Plant Anatomy: meristems, cells, and tissues of the plant body: their structure, functiion and development. 3ed. New Jersey: John Wiley \& Sons; 2006.

[123] Scatena VL., Dias ES. Parênquima, colênquima e esclerênquima. In: Appezzato-daGlória B., Guerreiro SMC. (eds.). Anatomia Vegetal. Viçosa: UFV. 2ed; 2006. p109-141.

[124] Marcati CR., Oliveira IS., Machado SR. Growth rings in cerrado woody species: occurrence and anatomical markers. Biota Neotropica; 2006 6(3) http://www.biotaneotropica.org.br/v6n3/PT/abstract?article+bn00206032006. (Accessed 24 July 2014)

[125] Esau K. Anatomy of Seed Plants. U.S.A.: John Wiley and Sons Inc. 2ed; 1977.

[126] Rajput KS., Rao KS. Secondary growth in the stem of some species of Alternanthera and Achyrantes aspera (Amaranthaceae). IAWA Journal 2000; 21(4) 417-429.

[127] Costea M., DeMason DA. Stem morphology and anatomy in Amaranthus L. (Amaranthaceae)-taxonomic significance. Journal of the Torrey Botanical Society 2001; 128 254-281.

[128] Mauseth JD. Plant Anatomy. California: The Benjamin/Cummings Publishing Company, Inc; 1988.

[129] Carlquist S. Wood and stem anatomy of woody Amaranthaceae s.s.: ecology, systematics and the problems of defining rays in dicotiledons. Botanical Journal of the Linnean Society 2003; 14: 1-19. 
[130] Raunkiaer C. The life forms of plants and statistical plant geography. Oxford: Clarendon Press; 1934.

[131] Appezzato-da-Glória B. Morfologia de sistemas subterrâneos-histórico e evolução do conhecimento no Brasil. Ribeirão Preto, Brazil: A.S. Pinto Editor; 2003.

[132] Lindman CAM., Ferri MG. A vegetação do Rio Grande do Sul. Belo Horizonte: Ed. Itatiaia; São Paulo: EDUSP; 1974.

[133] Rachid M. Transpiração e sistemas subterrâneos da vegetação de verão dos campos Cerrados de Emas. Boletim da Faculdade de Filosofia Ciências e Letras da Universidade de São Paulo, 80 (Botânica) 1947; 5 5-140.

[134] Rizzini CT., Heringer EP. Studies on the underground organs of trees and shrubs from some southern Brazilian savannas. Anais da Academia Brasileira de Ciências $1962 ; 34$ 235-247.

[135] Paviani TI. Estudos morfológico e anatômico de Brasilia sickii G. M. Barroso. II: anatomia da raiz, do xilopódio e do caule. Revista Brasileira de Biologia 1977; 37(2) 307-324.

[136] Appezzato-da-Glória B., Estelita MEM. The developmental anatomy of the subterranean system in Mandevilla illustris (Vell.) Woodson and M. velutina (Mart. ex Stadelm.) Woodson (Apocynaceae). Revista Brasileira de Botânica 2000; 23 7-35.

[137] Bell AD., Brian A. Plant form-an illustrated guide to flowering plant morphology. Portland, USA; London, England: Timber Press, Inc; 2008.

[138] Hoffmann WA. The relative importance of sexual and vegetative reproduction in Cerrado woody plants. In: Cavalcanti TB., Walter BMT. (eds.), Tópicos atuais em botânica-palestras convidadas do $51^{\circ}$ Congresso Nacional de Botânica. Brasília: Sociedade Brasileira de Botânica/Embrapa-Cenargen; 2000. p231-234.

[139] Figueiredo-Ribeiro RCL., Dietrich SMC., Carvalho MAM., Vieira CCJ., Isejima EM., Dias-Tagliacozzo GM., Tertuliano MF. As múltiplas utilidades dos frutanos-reserva de carboidratos em plantas nativas do cerrado. Ciência Hoje 1982; 14(84) 16-18.

[140] Figueiredo-Ribeiro RCL. Distribuição, aspectos estruturais e funcionais dos frutanos, com ênfase em plantas herbáceas do cerrado. Revista Brasileira de Fisiologia Vegetal 1993; 5(2) 203-208.

[141] Vieira CCJ., Figueiredo-Ribeiro RCL. Fructose-containing carbohydrates in the tuberous root of Gomphrena macrocephala St.-Hil. (Amaranthaceae) at different phenological phases. Plant, Cell and Environmentm 1993; 16 919-928.

[142] Moreira MF., Vieira CCJ., Zaidan LBP. Efeito do fotoperíodo no crescimento e no padrão de acúmulo de frutanos em plantas aclimatizadas de Gomphrena macrocephala St.-Hil. (Amaranthaceae). Revista. Brasileira de Botânica 1999; 22(3)3 397-403.

[143] Silva FG., Cangussu LMB., Paula SLA., Melo GA., Silva EA.. Seasonal changes in fructan accumulation in the underground organs of Gomphrena marginata Seub. 
(Amaranthaceae) under rock-field conditions. Theoretical and Experimental Plant Physiology 2013; 25(1) 46-55.

[144] Barros MGAE. Plantas medicinais-usos e tradições em Brasília-DF. Oréades 1982; 8 (14/15) 140-149.

[145] Pio Corrêa M. Dicionário de plantas úteis do Brasil e das exóticas cultivadas. Brasília: Ministério da Agricultura/IBDF; 1984.

[146] Siqueira JC. Importância alimentícia e medicinal das amarantáceas do Brasil. Acta Biologica Leopoldinensia 1987; 9 (1) 99-110.

[147] Lorenzi H., Matos FJA. Plantas medicinais no Brasil-nativas e exóticas. Nova Odessa, Brazil: Editora Plantarum, 2ed.; 2008.

[148] Kardošová A., Ebringerová A., Alföldi J., Nosál'ová G., Fraňová S., Hřıbalová V. A biologically active fructan from the roots of Arctium lappa L., var. Herkules. International Journal of Biological Macromolecules 2003; 33 (Nov 2003) 135-140.

[149] Faleiros FG., Farias Neto, AL. Savanas - desafios e estratégias para o equilíbrio entre a sociedade, agronegócio e recursos naturais. Planaltina-DF, Brazil: Embrapa Cerrados, 2008.

[150] Embrapa Cerrados, Unidade, História. 2012. Brasília: Embrapa. http:// www.cpac.embrapa.br/unidade/historia/ (acessed 25 August 2014).

[151] Pinheiro, MHO. Formações savânicas mundiais: uma breve descrição fitogeográfica. Brazilian Geographical Journal: Geosciences and Humanities research medium 2010; 1 (2) 306-313.

[152] Williams RJ., Myers, BA., Muller WJ., Duff GA., Eamus D. Leaf phenology of woody species in a north Australian tropical savanna. Ecology 1997; 78(8) 2542-2558.

[153] Kerr LR. The lignotubers of Eucalyptus seedlings. Proceedings of the Royal Society of Victoria 1925; 37 79-97.

[154] Mibus R., Sedgley M. Early lignotuber formation in Banksia-Investigations into the anatomy of the cotyledonary node of two Banksia (Proteaceae) species. Annals of Botany 2000; 86 575-587.

[155] Johansen DA. Plant Microtechnique. London: McGraw-Hill; 1940.

[156] Harborne JB. The evolution of flavonoid pigments in plants. In: T. Swain (ed.). Comparative phytochemistry. London: Academic Press; 1966. p271-295.

[157] Montesinos E. Plant-associated microorganisms: a view from the scope of microbiology. International Microbiology 2003; 6 221-223.

[158] Rocha R., Luz DE., Engels C., Pileggi SAV., Jaccoud Filho DS., Matiello RR., Pileggi M. Selection of endophytic fungi from comfrey (Symphytum officinale L.) for in vitro 
biological control of the phytopatogen Sclerotinia sclerotiorum (LIB.). Brazilan Journal of Microbiology 2009; 40 73-78.

[159] Siqueira JC. O Bioma Cerrado e a preservação de grupos taxonômicos: um olhar sobre as Amaranthaceae. Pesquisas, Botânica 2007; 58 389-394.

[160] Martinelli LA., Joly CA., Nobre CA., Sparovek G. A falsa dicotomia entre a preservação da vegetação natural e a produção agropecuária. Biota Neotropica 2010; 10(4) http://www.biotaneotropica.org.br/v10n4/pt/abstract?point-of-iew+bn00110042010 (accessed 27 July 2014). 